\title{
Did prehistoric and Roman mining and metallurgy have a significant impact on
}

\section{vegetation?}

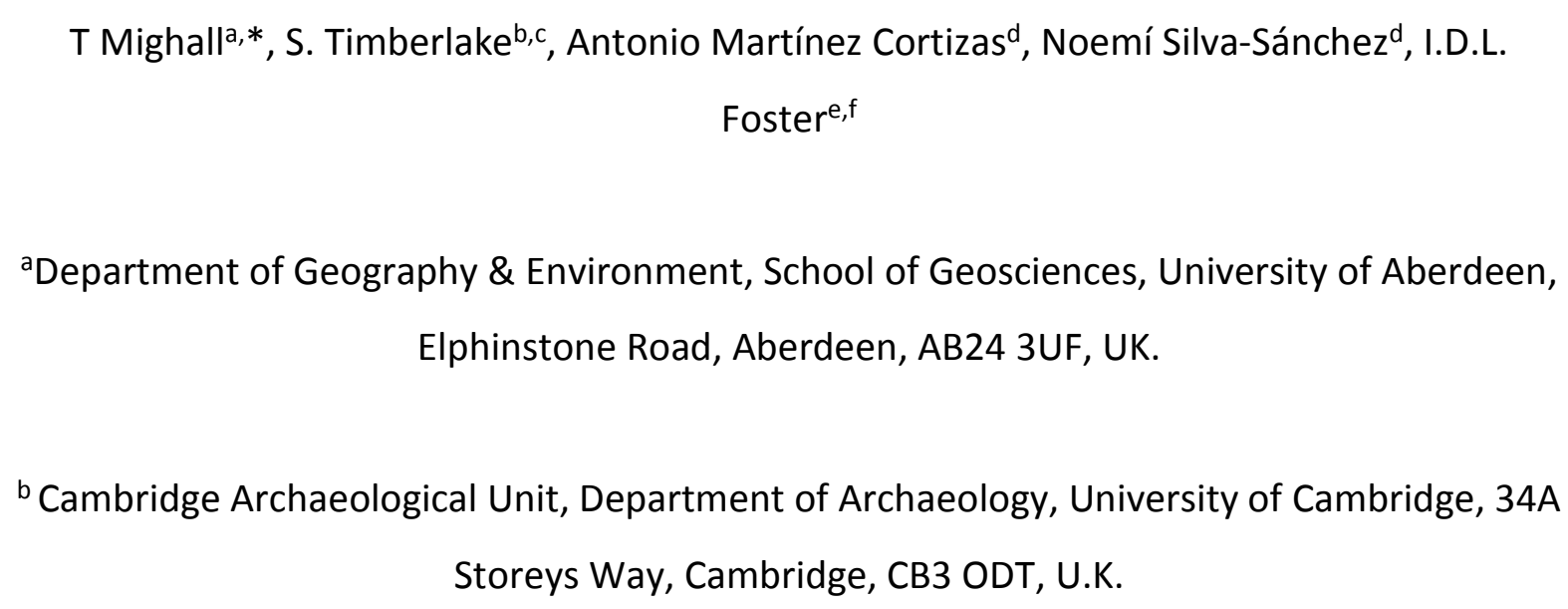

aDepartment of Geography \& Environment, School of Geosciences, University of Aberdeen, Elphinstone Road, Aberdeen, AB24 3UF, UK.

${ }^{b}$ Cambridge Archaeological Unit, Department of Archaeology, University of Cambridge, 34A Storeys Way, Cambridge, CB3 ODT, U.K.

'Early Mines Research Group, Ashtree Cottage, 19, The High Street, Fen Ditton, Cambridgeshire, CB5 8ST, U.K.

\begin{abstract}
${ }^{d}$ Departamento de Edafología y Química Agrícola, Facultad de Biología, Universidad de Santiago, Campus Sur, 15782 Santiago de Compostela, Spain.
\end{abstract} eSchool of Science and Technology, University of Northampton, Newton Building, Northampton NN2 6JD, UK
fDepartment of Geography, Rhodes University, Grahamstown 6140, Eastern Cape, South Africa

*corresponding author: E-mail address: t.mighall@abdn.ac.uk

Abstract

To develop our understanding of the relationship between vegetation change and past mining and metallurgy new approaches and further studies are required to ascertain the 
significance of the environmental impacts of the metallurgical industry. Using new pollen and geochemical data from Cors Fochno (Borth Bog), Wales, we examine whether prehistoric and Roman mining and metallurgy had a significant impact on the development of vegetation and compare the findings with previous studies across Europe on contamination and vegetation change to develop a conceptual model. The evidence suggests that early mining and metallurgy had a minimal impact on vegetation, especially woodlands, with small-scale, non-permanent phases of woodland clearance. The impact was more severe during Roman times, but very few sites show woodland clearance followed by regeneration. Records do suggest that woodlands underwent compositional changes in tandem with increased atmospheric pollution, possibly in part as a result of demands for wood fuel for mining and metallurgy, but otherwise woodlands show a degree of resilience. The results from Cors Fochno suggest that vegetation changes that occurred during periods of mining and metallurgy, as inferred from changepoint analysis, were insignificant compared to later periods, including Roman times.

Keywords: mining, metallurgy, pollen, changepoint analysis, Bronze Age, Roman, woodlands

\section{Introduction}

The advent of mining and metallurgy in the Chalcolithic-Early Bronze Age represents one of the most significant social, technological and (potentially) environmental transformations in human history. Over the last two decades there has been an upsurge in interest in the environmental impacts of this transformation, primarily focusing on two areas: metal contamination and vegetation change. A number of studies have reconstructed the pollution history of past mining and metallurgy in Europe, particularly of metals considered 
to be immobile in ombrotrophic peat such as lead $(\mathrm{Pb})$ and copper $(\mathrm{Cu})$ (e.g. Monna et al., 2004; Kylander et al., 2005; Küttner et al., 2014), the Near East (e.g. Pyatt et al, 2000) and North America (e.g. Pompeani et al., 2013) to establish the timing, severity and longevity of metal contamination which now extends back to the Early Bronze Age in Europe (e.g. Mighall et al., 2002a; Garcia-Alix et al., 2013; Pontevedra-Pombal et al., 2013; Martínez Cortizas et al. 2016).

62

Until recently the impact of mining and metallurgy on vegetation was poorly understood but investigations in regions with a long history of ferrous and non-ferrous mining and metallurgy are beginning to rectify this situation (e.g. Küster and Rehfuess 1997; Breitenlechner et al., 2010; López Merino et al., 2013; Mighall et al., 2010; 2012; Viehweider et al., 2015). These studies include those that are specific to a mine or furnace (e.g. Mighall et al., 1993; 2002a, b; Mighall et al., 2000; Myrstener et al., 2016) and those that are more regional in scope (e.g. Mighall et al., 2009; Silva-Sánchez et al., 2015). As mining and metallurgy does not occur in isolation and other activities, such as agriculture, occurred during periods of industrial activities, numerous studies have benefited by combining records of metals associated with pollution in tandem with pollen records to discriminate between industrial activity and other land use changes, but have also debated the impact mining and/or metallurgy had on vegetation, particularly woodlands: whether they were largely destroyed by mining and metallurgy or not. A series of studies now suggest that in prehistoric times mining/metallurgy did not have an adverse impact on woodlands (e.g. Marshall et al., 1999; Mighall et al., 2004; Jouffroy-Bapicot et al., 2007; Breitenlechner et al., 2010, 2013; Bindler et al., 2011; Viehweider et al., 2015) with Mighall and Chambers (1997) suggesting that any impact was influenced by some form of management, selectivity, the 
scale and duration of ironworking as well as other land use strategies. A further

methodological advance is the use of changepoint analysis on such data which now allows

82 us to assess the significance of environmental changes more objectively (Gallagher et al.,

83 2011) and has been applied successfully to datasets derived from bogs (e.g. Kylander et al.,

84 2013; Hansson et al., 2013; Martínez Cortizas et al., 2016).

In order to establish the impact of mining and/or metallurgy on woodlands more studies are needed. Therefore we present new pollen and geochemical data from Cors Fochno (Borth Bog) to exemplify whether such activities had a significant impact on the vegetation history at the site and compare the findings with previous studies across Europe to identify patterns in the data that could lead to a conceptual model of such impacts. This will be accomplished by discriminating between environmental changes caused by mining and metallurgy from other types of land use by performing principal component analysis on the geochemical data, and to identify significant vegetation changes were caused by mining and/or metallurgy using changepoint analysis.

\section{Site details and context}

97 Over 250 archaeological sites are recorded on the Dyfed Historic Environment Record in and around the Cors Fochno, ranging in date from Mesolithic find spots to twentieth century military installations (Page et al., 2012). One of the most important archaeological discoveries is the evidence for early mining of metal-bearing deposits including chalcopyrite

101 (copper iron sulphide), galena (lead sulphide) and sphalerite (zinc sulphide) (Timberlake, 1995a, b, 1996a, 2003a). Eight Early Bronze Age mines have been identified in mid- and north Wales, including an area of prehistoric prospection and mining around Cors Fochno 
104 (Figure 1a-c). Bronze Age copper mining is suspected at Llancynfelin, Pwll Roman and

105 Erglodd along the western fringe of the bog (Timberlake, 2006) but some may have been

106 prospecting rather than actual mining (Timberlake, 2009) (Figure 1c). Roman lead smelting

107 also occurred at Llancynfelin, close to the Erglodd Roman fort during the first century AD

108 (Page et al., 2012; Figure 1b). The Blaen yr Esgair Roman road has been radiocarbon-dated

109 to c. AD 80. Mighall et al. (2009) presented a record of metal contamination that suggests

110 lead mining and/or metallurgy surrounding the bog occurring in the Bronze Age, late Iron

111 Age and Roman times.

112

113 Cors Fochno (Borth Bog) is an estuarine lowland raised bog located in northern Ceredigion,

114 north of Aberystwyth that forms part of the Dyfed SSSI and National Nature Reserve and a

115 UNESCO Biosphere Reserve. The bog is approximately 200 ha in extent and surrounded by a

116 further 400 ha of degraded bog that has suffered from past peat cutting and drainage

117 (Poucher, 2009). A full description of the bog is provided in Hughes and Schulz (2001). Cors

118 Fochno is underlain by Silurian Aberystwyth grits group with outcrops of Ashgill beds

119 (mudstones and siltstones to the east) (Howells, 2007).

120

121 Pollen diagrams have been published from Cors Fochno (Borth Bog) by Godwin and Newton

122 (1938), Godwin (1943) and Moore (1968). All three studies are constrained by the absence

123 of radiometric dating and Godwin only published tree pollen data. More recently, Page et

124 al. (2012) published pollen data for the site but this record focusses solely on the Late Iron

125 Age - Roman period. Other studies have focussed upon mire development (Hughes and

126 Schulz, 2001; Hughes et al. 2007). Given the limitations of the pollen-based studies and the 
127 recent discovery of new archaeological sites surrounding the bog (outlined below), a new

128 investigation is timely.

129

130 The location of the sampling sites in this study is shown in figure $1 \mathrm{c}$. The coring location is

131 SN63548 91373, elevation 3 \pm 5 m OD. A 7 m-deep core was taken from the raised bog to

132 provide a regional record of pollution and vegetation change. The top $4 \mathrm{~m}$ of the core are

133 considered in this paper as it covers the period of interest.

134

135 3. Methods and materials

136

137 A core was collected using a 30-cm long, 9-cm wide Russian corer, wrapped in plastic, sealed

138 and stored in a cold store prior to sub-sampling for geochemical and microfossil analyses.

1403.1 Dating methods: Five peat samples were carefully extracted and submitted to the Beta

141 Analytical, Miami or Poznań radiocarbon laboratory for AMS radiocarbon dating (Table 1).

142 Three of the samples comprised bulk sediment, whilst two (BB52-53 cm and 170-171cm)

143 were Sphagnum leaves.

144

$145{ }^{210} \mathrm{~Pb}$ dating was undertaken on $1 \mathrm{~cm}$ thick contiguous samples taken from the upper $20 \mathrm{~cm}$

146 of the core to define more precisely the age of the uppermost part of the sequence and to

147 detect any hiatus in modern peat accumulation. Full details of energy and efficiency

148 calibration methods, and of quality control, are given by Foster et al. (2005) and Mighall et

149 al. (2009). ${ }^{214} \mathrm{~Pb}$ was measured in order to obtain ${ }^{226} \mathrm{Ra}$ activities that were subtracted from

150 the total ${ }^{210} \mathrm{~Pb}$ activity to calculate the unsupported $\left({ }^{210} \mathrm{~Pb}\right.$ un $)$ component in the samples. 
152 3.2. Geochemistry: Concentrations of major elements ( $\mathrm{Si}, \mathrm{Al}, \mathrm{Fe}, \mathrm{Ca}, \mathrm{K})$, trace lithogenic

153 elements ( $\mathrm{Rb}, \mathrm{Sr}, \mathrm{Ti}, \mathrm{Zr}, \mathrm{Y})$ and trace metals/metalloids $(\mathrm{Cu}, \mathrm{Cr}, \mathrm{Zn}, \mathrm{Ni}, \mathrm{Pb}$ and $\mathrm{As}$ ) were

154 obtained by energy dispersive X-ray fluorescence (EMMA-XRF) analysis (Cheburkin and

155 Shotyk, 1996; Weiss and Shotyk 1998). The instruments are hosted at the RIAIDT

156 (Infrastructure Network for the Support of Research and Technological Development)

157 facility of the University of Santiago de Compostela (Spain). Standard reference materials

158 were used for the calibration of the instruments. Quantification limits were $0.001 \%$ for Ti,

$1590.01 \%$ for $\mathrm{Si}, \mathrm{Al}$ and $\mathrm{Fe}, 0.5 \mu \mathrm{g} \mathrm{g}^{-1}$ for $\mathrm{Pb}, 10 \mu \mathrm{g} \mathrm{g}{ }^{-1}$ for $\mathrm{Cr}$ and $1 \mu \mathrm{g} \mathrm{g}^{-1}$ for the other elements.

160 Replicate measurements were performed on one of every five samples in order to account

161 for reproducibility; all replicates agreed within 5\%. Loss on ignition percentages (LOI) were

162 also determined following Schulte and Hopkins (1996).

163

164 3.3. Microfossils: Sub-samples of $1 \mathrm{~cm}$ thickness were prepared for pollen and non-pollen palynomorph (NPPs) analyses following Barber (1976). A minimum sum of at least 300 total

166 land pollen (TLP) was achieved for all sub-samples in order to produce a statistically

167 significant result (Birks \& Birks, 1980). Data are expressed as a percentage of the TLP, with

168 spores and aquatic taxa excluded from the TLP sum. NPPs were also counted (cf. van Geel et al. 1982/1983, 2003) and they are expressed as a percentage of TLP plus total NPPs. Rare

170 types are indicated by a cross $(+)$, where one cross is equal to one pollen grain or NPP.

171 Pollen samples were spiked with Lycopodium clavatum tablets (Stockmarr, 1971).

172 Microscopic charcoal was counted during routine pollen analysis. Pollen identification,

173 including cereal-type pollen, was aided by reference keys in Fægri et al. (1989), Moore et al.

174 (1991) and Reille (1999), and supported by a modern type-slide reference collection. As the 
separation of Myrica gale from Corylus avellana-type can be difficult these pollen grain types are classified as Corylus avellana-type (Edwards 1981). Plant nomenclature follows Stace (2001). Non-pollen palynomorphs were identified using van Geel (1978), van Geel et al. $(2005 ; 2006)$.

3.4 Statistics: The use of multivariate statistical approaches helps to summarize common patterns of variation and to gain insights into the underlying environmental factors.

Therefore, principal component analyses (PCA) was applied to the geochemical data using SPSS 20, in correlation mode and by applying a varimax rotation (Silva-Sánchez et al., 2014). Prior to analysis the dataset was standardized using z-scores, which avoids scaling effects and gives average-centred distributions (Eriksson, 1999). Changepoint (CP) modelling was applied to the pollen data (total trees, shrubs, herbs) to detect significant changes in the pollen record statistically. This approach is based on Bayesian transdimensional Markov chain Monte Carlo (for more details see Gallagher et al., 2011).

\section{Results}

4.1 Stratigraphy: The core was taken from the central area of the raised bog with Myrica gale, Calluna vulgaris, Eriophorum, Molinia and Sphagna characterising the surface vegetation. The core was $7 \mathrm{~m}$ in length and consists primarily of Sphagnum peat of varying stages of decomposition in the top $5.6 \mathrm{~m}$, overlying an herbaceous (Phragmites) peat sitting on top of estuarine clay at $6.94 \mathrm{~m}$. A full description of the stratigraphy is provided in Mighall et al. (2009). At the time of coring, the water table was close to surface at approximately $10-15 \mathrm{~cm}$ depth. 
4.2. Dating: All radiocarbon dates quoted in this paper are listed in Table 1 . The uncalibrated radiocarbon dates and calibrated ages cited to $2 \sigma$ age, using Calib 7.1 software (Reimer et al., 2009) in conjunction with Reimer et al. (2013). The cic and $c r{ }^{210} \mathrm{~Pb}_{\text {un }}$ dating calculations of Appleby and Oldfield (1978) were both used to establish a chronology for the upper 20 $\mathrm{cm}$ of the peat section for the core. Full details can be found in Mighall et al. (2009). The analysis suggests that the record of modern peat accumulation, extending back approximately 150 years, has been preserved at this location, although earlier phases of peat cutting cannot be eliminated on the basis of these results. Both the radiocarbon dates and ${ }^{210} \mathrm{~Pb}_{\text {un }}$ dating were used to construct an age-depth model using CLAM (Blaauw, 2010) (Figure 2). All dates are rounded to the nearest half decade and are expressed in calendar years $A D / B C$ unless stated otherwise. 0 BP is equated to $A D 1950$.

210

4.3. Loss-on-ignition \& geochemistry: LOI values fluctuate between $97-98 \%$ from $400 \mathrm{~cm}$ to $300 \mathrm{~cm}$. One value at $120 \mathrm{~cm}$ dips to below $96 \%$ then they regularly exceed $98 \%$ thereafter

213 (Figure 3).

Four components, with eigenvalues greater than 1 , account for $83 \%$ of the total variance of the chemical composition of the peat samples (Cp1 32.4\%, Cp2 28.7\%, Cp3 12.8\% and Cp4 9\%) but only three are discussed as Cp4 offers no useful insights. The record of scores of the

218 first three components are shown in Figure 4 and the fractionation of communalities in supplementary figure 1 . Most major and trace lithogenic elements ( $\mathrm{Ti}, \mathrm{Zr}, \mathrm{Si}, \mathrm{Rb}, \mathrm{Al}$, and $\mathrm{Y}$ ) show large positive loadings in Cp1 (Table 2; Supplementary figure 2), while K shows a moderate loading. Small proportions (11-17\%) of the variance of metals like $\mathrm{Fe}, \mathrm{Pb}$ and $\mathrm{Cu}$, are also allocated to this component. The depth distribution of scores (Figure 4) shows low 
223 variation below $150 \mathrm{~cm}$, with small peaks at 349, 297 and $257 \mathrm{~cm}$ depth. Above $150 \mathrm{~cm}$

224 values are more variable with larger and more discernible peaks at 149, 121, 69, 49, 41 and

$2258 \mathrm{~cm}$.

226

$227 \mathrm{Cp} 2$ is characterised by large ( $\mathrm{Fe}, \mathrm{Pb}, \mathrm{Zn}, \mathrm{As}, \mathrm{Cu}$ ) and moderate (Ni) positive loadings of 228 metallic elements (Table 2; Supplementary figure 2). Some lithogenic elements, as $\mathrm{Y}, \mathrm{K}$ and $229 \mathrm{Si}$, also have part (10-36\%) of their variance in this component. The record of scores (Figure 230 4) shows almost constant values until $37 \mathrm{~cm}$ depth, from which values increase abruptly to

231 the top of the core. It is noticeable that the large peaks in Cp1 scores in the upper $150 \mathrm{~cm}$ of 232 the core coincide with decreases in Cp2 scores.

$234 \mathrm{Cp} 3$ is almost exclusively related to the variation of $\mathrm{Ca}$ and $\mathrm{Sr}$ concentrations. The scores 235 show negative values below $297 \mathrm{~cm}$, a brief increase from 297 to $285 \mathrm{~cm}$, another decrease 236 until $255 \mathrm{~cm}$, to increase suddenly to positive values and remain high until $69 \mathrm{~cm}$. From this 237 depth to the surface, values decrease to negative scores then increase slightly again in the 238 upper $9 \mathrm{~cm}$ of the core (Figure 4).

239

240 4.4. Microfossils: The pollen and NPP diagrams were constructed using Tilia.graph (Grimm, $2412004)$ and selected taxa are presented in Figure 5a-c. The diagrams have been divided into 242 local pollen assemblage zones (LPAZs) guided by CONISS (Grimm 1987). Full diagrams are provided in supplementary figures 3a-c. 
4.5. Changepoint analysis: The changepoint analysis results are shown in Figure 6.

Significant changepoints occur at c. 2400 BC, 1950 BC, 1000 BC, 780 BC, 500 BC, 0 AD/BC,

AD 200, AD 1200, AD 1375 and in the last 200 years.

\section{Interpretation and chronology of the changes}

250

5.1 Geochemistry: $\mathrm{Cp} 1$ is characterised by positive loadings of lithogenic elements ( $\mathrm{Ti}, \mathrm{Zr}, \mathrm{Si}$, $\mathrm{Rb}, \mathrm{Al}, \mathrm{Y}, \mathrm{K})$, which may reflect variations in the mineral content of the peat due to changes in atmospheric dust deposition, probably linked to soil erosion (Table 2). The Cp1 record (Figure 4) indicates low dust deposition before the late Iron Age-Roman period, with a few dust events dating to $2440,1600-1500$ and 1000 BC. From the late Iron Age-Roman period, the number and intensity of the dust-deposition events increased, peaking at c. $30 \mathrm{BC}, \mathrm{c}$. $A D$ 280, c. AD 660, c. AD 940, c. AD 1160-1420 and c. AD 1880-1950.

258

$\mathrm{Cp} 2$ is reflecting a relatively recent (historical) increase in the deposition of metals, most possibly as a result of (poly-metallic)-atmospheric pollution. The record of scores (Figure 4) shows almost constant values until c. AD 1500 and a rapid increase thereafter. Minor fluctuations, for example, between 290 and $275 \mathrm{~cm}, 240 \mathrm{~cm}$ and $210 \mathrm{~cm}$ do occur and they could represent slight changes in the intensity of dust deposition. This pollution signal was somewhat masked during episodes of intense atmospheric dust deposition (i.e. enhanced soil erosion). Nevertheless, the fact that a few lithogenic elements ( $\mathrm{Y}, \mathrm{K}, \mathrm{Si})$ also load partly on this component points to a contribution by dust deposition, most likely related to mining operations rather than to metallurgically-derived metal emissions. 
Cp3 is likely to reflect a mineralogical/source effect. Elements with large loadings in Cp1 occur in higher concentrations in acidic rocks and soils (hosted in silicates as K-feldspars and muscovite), while the elements characterising Cp3 have higher concentrations in calcalkaline and basic rocks (e.g. rich in plagioclase and amphibole) and they are also typical of carbonates. Thus, this component traces changes in the source of part of the atmospheric dust deposited in the mire. While $\mathrm{Cp} 1$ elements and related minerals probably derive from the dominant local geology (Silurian mudstones and sandstones), no geological material in the immediate surroundings of the mire seems to contain Ca-rich minerals; but intrusive and extrusive volcanic rocks of Ordovician age, located approximately a few tens of kilometres north and east of Cors Fochno, may contain large amounts of plagioclase and amphibole. Thus, changes in $\mathrm{Cp} 3$ scores may reflect regional rather than local dust sources. The Ca-rich dust source seems to have been less active from c. 3500 to 1000 BC, except for a brief phase between c. $1600-1380$ BC; from c. 1000 BC to AD 1000, it made a significant contribution to the dusts deposited on Cors Fochno mire, decreased sharply until the mid AD 18th century and resumed its contribution up until the present.

The variance of some of the metals ( $\mathrm{Fe}, \mathrm{Pb}$ and $\mathrm{Cu}$ ) is related in part to $\mathrm{Cp} 1$, indicating that their content in Cors Fochno peat also has a geogenic origin. In contrast, the chronology of scores of the metal signal reflects recent rather than earlier metal pollution. The PCA results suggest that most of the metal pollution $(72-70 \%$ of the Fe and $\mathrm{Pb}$ variance, $68-59 \%$ of that of $\mathrm{Zn}, \mathrm{As}$ and $\mathrm{Cu}$, and $30 \%$ of that of $\mathrm{Ni}$ ) occurred in the last 500 years and may have been related to mining/metallurgy. The extracted components do not reveal the history of preindustrial metal contamination: this signal is not strong and its history may have been different for each metal. To determine if the record of concentrations contains information 
on other sources of pollution we extracted the residual variance for $\mathrm{Pb}, \mathrm{Zn}$ and $\mathrm{As}$ ( $\mathrm{rPb}, \mathrm{rZn}$,

294 rAs) i.e. the variation in metal concentrations not explained by recent poly-metallic pollution

295 or by changes in soil dust influx (Figure 7). This was done by detrending the record of the metal concentrations (in Z scores) from the components in which its variance is allocated

297 (Cp1 and Cp2 outlined above). Relatively elevated values were detected for each element. Eight phases are detected for Pb: >c. 2980 BC, c. $1500-900$ BC, c. $630-540$ BC, C. 300 BC to c. AD 100, c. AD 330-560, c. AD 1000, c. AD 1420-1700, and from c. AD 1800 to show an abrupt decline in recent decades; five phases for $\mathrm{Zn}$ : c. 2670-1700 BC, c. 540-350 BC, c. 30 BC, c. AD 280, c. AD 800-1800; and six phases for As: c. 1600-1000 BC, c. 230 BC, c. 30 BC, c. AD 280, c. AD 940, c. AD 1270-1690 and c. AD 1925. These variations seem to reconstruct both preindustrial and industrial $\mathrm{Pb}$ pollution (ancient mining and metallurgy, coal burning, combustion of fossil fuels, etc.) and compare favourably to those presented by Mighall et al. (2009). The record of Cu residual variance did not show significant changes (probably because most of the concentrations are close to the limit of detection), while Fe residual variance is difficult to interpret due to the redox behaviour of this element.

5.2 Pollen \& NPPs: LPAZ CF1a (400-347 cm; c. $3300-2400 \mathrm{BC})$ : is characterised by

fluctuations in total arboreal pollen (trees and shrubs), mainly variations in the percentages of the dominant tree taxa (Quercus, Betula and Alnus) and Corylus avellana-type. These variations might be the result of disturbance although evidence of human activity in the pollen diagram is mute. Poaceae percentages were low and non-arboreal pollen taxa associated with cultural affinities only occurred sporadically and in trace amounts: for example, Artemisia-type, Aster-type, Plantago lanceolata, Plantago media/major, 
small-scale or of insufficient intensity to be registered in the more central parts of the bog

318 (Figure 5a, b).

319

320

LPAZ CF1b (347-325 cm; c. 2400-2030 BC): This represents a period of high arboreal tree and

321 shrub percentages. Total tree pollen initially increased, coincident with a substantial but

322

temporary decrease in Corylus avellana-type, at the end of LPAZ CF1a and throughout LPAZ

323

CF1b. Notwithstanding the occasional, short-lived recovery, phases of woodland

324

interference is further indicated by a gradual decline in total tree pollen with Quercus, and,

325

to a lesser extent, Betula and Alnus, but total arboreal pollen values remain high compared

326

with the previous zone.

327

328

There was a sustained increase in Poaceae and Plantago lanceolata occurs regularly. Rumex

acetosa-type and Ranunculaceae were recorded and Aster-type occurred more sporadically

in trace amounts indicative of minor disturbance and/or pasture. Sordaria-type (HdV55A/B)

was recorded for the first time suggesting low intensity grazing and/or the presence of decayed wood (Figure 5c).

LPAZ CF1c (325- $301 \mathrm{~cm}$; c. $2030-1630$ BC): Total arboreal percentages are much lower in the sub-LPAZ: the major trees all decline. The decline of Alnus and Betula, suggests that clearance took place on the wetter fringes of the bog and with UImus and Quercus affected on drier substrates. Quercus decreased quite rapidly. Corylus avellana-type recovers to approximately its CF1a LPAZ values. Hazel scrubland appears to have replaced mixed woodland but some of the increase in Corylus avellana-type might be in response to Myrica gale colonising more minerotrophic conditions prevalent on the edge of the bog. 
342 Evidence for agriculture and/or disturbance, as described in the previous sub LPAZ

343 continues. The first occurrence of cereal-type pollen was recorded c. 1960 BC and coincided

344 with a small peak in microscopic charcoal and a decline in Quercus, Betula and Alnus,

345 although Corylus avellana-type increased in value. Fire could have been used to clear

346 woodland for agriculture but wood was used for mining activity and the microscopic

347 charcoal peaks might represent the burning of branchwood in the mines to break up the ore

348 (commonly referred to as firesetting).

LPAZ CF1d (301-265 cm; c. 1630-1090 BC): Woodland (mainly Quercus, Alnus and Betula)

regenerated gradually throughout LPAZ CF1d, as indicated by the increase in total arboreal pollen percentages. In contrast, Alnus initially declined along with Corylus avellana-type, which suggests that any clearance was concentrated on wetter substrates, perhaps on the

354 fringe of the bog. Bog plants also responded, including a rise in Calluna and Sphagnum, which also implies that they might be replacing Myrica. Notwithstanding any taphonomic effect on the pollen rain, taxa indicative of pasture and/or disturbance were recorded at the start and end of the LPAZ: Poaceae, Plantago lanceolata, Artemisia-type and Pteridium peak, and Aster-type, Rumex acetosa type and Ranunculaceae were recorded in trace amounts (Brown et al., 2007). Cereal-type pollen was also present (Figures 5a, b).

LPAZ CF1e (265 cm-249 cm; c. 1630-900 BC): A phase of woodland clearance occurs significant, permanent decline in woodland during the mid to late Bronze Age. Poaceae, 
Plantago lanceolata, Potentilla-type and Pteridium initially peaked and trace amounts of

Artemisia-type, Rumex acetosa-type, Chenopodiaceae and Ranunculaceae were recorded.

366

367 LPAZ CF2 (249- 205 cm; c. 900-520 BC): Woodland recovers slightly at the start of the LPAZ.

368 Quercus, Betula and Alnus all increase in value. Evidence for human activity in the non-

369 arboreal record is then mute at this time. In contrast, Calluna percentages rose across the

370 LPAZ sub zone boundary and this sudden increase might have masked any human

371 disturbance signal in the pollen record as plants within a couple of metres of the sampling

372 point can dominate the pollen assemblage and therefore proportions of those taxa associated with land use changes in the wider landscape may be poorly represented

374 (Bunting, 2003). As Calluna percentages began to decrease by $230 \mathrm{~cm}, \mathrm{c} .700 \mathrm{BC}$, human activity was more evident with the occurrence of cereal-type pollen and an increase in Plantago lanceolata percentages. The sudden peak in microscopic charcoal was most likely to have been caused by a short-lived fire close to the sampling site.

In the latter stages of the LPAZ, tree cover, reflected by much lower pollen percentages, reached a LPAZ minimum at $214 \mathrm{~cm}, \mathrm{c} .600 \mathrm{BC}$. Hazel scrub woodland appears to have been more dominant, as Corylus avellana-type percentages started to increase mid-LPAZ.

Plantago lanceolata increased but some cultivation is suggested by the isolated occurrence of cereal-type pollen.

386 LPAZ CF3 (205- $145 \mathrm{~cm}$, c. 520 BC- AD 20): The period of woodland regeneration across the LPAZ CF2/3 boundary. Total tree percentages remained fairly stable throughout the Iron Age 
388 (LPAZ CF3) but Corylus avellana-type percentages decreased substantially. Land was being

389 used for pasture and cultivation: indicators include a slight increase in Poaceae, Plantago

390 lanceolata continued to be well represented and a suite of non-arboreal taxa occurred,

391 albeit sporadically and in trace amounts, including Ranunculaceae, Urticaceae,

392 Chenopodiaceae, Rumex acetosa-type, Potentilla-type, Aster-type, Artemisia-type and

393 Anthemis-type. Low percentages of 'anthropogenic indicator' taxa probably originated from

394 the wider landscape rather than agricultural activity in the near vicinity of the sampling

395 point (Bunting, 2003). Cereal-type pollen was also recorded. Cercophora-type, Sordaria-type

396 and Chaetomium sp. are also suggestive of low intensity grazing and/or the presence of

397 decayed wood (Figure 5c). The spores of the wood rot fungus, Kretzschmaria deusta is

398 indicative of possible woodland openings (Innes et al., 2006). Microscopic charcoal values

399 also gradually increased, suggesting that natural or deliberate fires were a regular

400 occurrence, possibly to clear woodland.

401

402 LPAZ CF4 (145-129 cm; C. AD 20 - 200): Woodland clearance accelerated across the LPAZ

403 CF3/4 boundary. All the major trees and shrubs were affected until the start of the Roman

404 period, until c. AD 70. Bog plants and NPPs seem to benefit most as a short-lived, sharp

405 increase in Calluna was followed by Cyperaceae and HdV-18. Bog surface conditions may

406 have been wetter as HdV-72A is indicative of pools of water and dry indicators such as HdV-

40710 decline (Figure 5c). This might have been influenced by climate as a stacked record of

408 proxy climate for northern Britain indicates a shift to wetter conditions c. 2050 Cal BP

409 (Charman et al., 2006). Evidence for arable and pastoral agriculture was still subtle. Poaceae

410 peaked just after LPAZ tree percentage minimum. Plantago lanceolata and Rumex acetosa-

411 type had a low, sustained presence and there were short-lived peaks or traces of Plantago 
412 media/major, Rumex acetosella, Lactuceae, Aster-type, Trifolium-type, Potentilla-type and

413 Chenopodiaceae, as well as one cereal-type pollen grain. Pteridium also increases in value.

414 (Figure 5b).

415

416 LPAZ CF5 (129-43 cm; c. AD 200 - 1380): Woodland regenerated more rapidly from c. AD

417210 , the start of LPAZ CF5. All the major trees and shrubs increased in representation until

418 the very end of the LPAZ. Poaceae and Plantago lanceolata percentages fell to lower values

419 but both taxa were still well represented. Cereal-type pollen was present at the start and

420 towards the end of the zone while pastoral indicators persisted albeit sporadically and in

421 trace amounts (Figure 5b). Sporadic occurrences of Tripterospora-type and Sordaria-type

$422(\mathrm{HdV} 55 \mathrm{~A} / \mathrm{B})$ suggest low intensity grazing and/or the presence of decayed wood (Figure 5c).

423 Woodland cover remained relatively stable as total arboreal pollen percentages fluctuated 424 around $40 \%$ TLP into the early medieval period.

425

426

LPAZ CF6 (43-9 cm; c. AD 1380 - 1920): A rapid phase of woodland clearance occurred

during the medieval and post medieval periods, commencing c. AD 1160 at the end of LPAZ

428

CF5 into CF6. All the major trees and shrubs were affected. Agricultural activities appear to have been an important driver of woodland clearance and soil erosion. Cereal-type pollen is relatively abundant. Poaceae and Plantago lanceolata percentages attain their highest values and a suite of taxa with pastoral affinities and the dung fungus Podospora type were present (Figure 5b, c).

434 LPAZ CF7 (9-0 cm; c. AD 1920-2000): The modern period is characterised by woodland regeneration, most notably Quercus and Corylus avellana-type. Pinus pollen percentages 
rose rapidly, indicative of plantations (Figure 6a). Helicon pluriseptatum (HdV30) may derive

from the plantations of Picea and Pinus (Yeloff et al., 2007). The evidence for agricultural

438 activity, described earlier for the medieval period, is still present but not as intense. Cerealtype pollen is recorded for the last time in trace amounts at the LPAZ boundary. The rise in charcoal is likely to have been caused by local bog or woodland fires and domestic activities.

\section{Discussion}

6.1: Vegetation change associated with human activity: The first significant change of

vegetation in the Cors Fochno pollen record occurs during the later Neolithic period (LPAZ shifts occurred between the trees and shrubs (Figure 6), most notably a decline in Corylus avellana-type and an increase in Quercus, Betula, Alnus and UImus and their reversal at $\sim 1950 \mathrm{BC}(320 \mathrm{~cm})$, which coincides with the onset of mining in the area based on archaeological evidence (Timberlake, 2006; Mighall et al., 2009). Taxa associated with disturbance and pasture are recorded throughout zone CF1, albeit in low amounts, which makes the evidence for human activity circumspect. If land was used for grazing, this activity did not produce a significant change in herbaceous taxa or overall woodland cover. Several small peaks in microscopic charcoal suggest that fire might have been used to clear small areas of woodland periodically (including around $\sim 2400$ BC) or people exploited natural openings.

LPAZ CF1c ( 2030 BC to c. 1630 BC) encompasses the age of range of the early mines in central Wales (between 1900 and 1700 Cal BC) (Timberlake, 2006) as well as the known early mines/prospecting sites more local to Cors Fochno. Of these, the oldest local workings 

radiocarbon date of $3800 \pm 40$ years BP $(2340-2130 \mathrm{BC})$ came from a sample of charcoal from the base of a mine spoil tip close to some stone hammers located at the eastern workings of Erglodd mine on the south eastern edge of Cors Fochno, less than $2 \mathrm{~km}$ from the coring site (Figure 1b). The rAs records do not show evidence of metal pollution during this phase, but rPb has a possible minor peak and rZn shows a moderate increase from c. 2670 to c. 1700 BC (Figure 7). In contrast a small Pb peak was reported by Mighall et al. (2009).

Notwithstanding the occasional reversal, total tree pollen percentages suggest that woodland clearance occurred between 1900 and 1700 BC. Clear impacts are recorded on individual taxa: for example, Quercus, Betula and Alnus although Corylus avellana-type increases. LOI also dips at 338 and $318 \mathrm{~cm}$ (Figure 3). The presence of cereal-type pollen and a suite of non-arboreal taxa often associated with pasture and disturbed ground (described earlier) suggest that land was also cultivated and used for pasture. Fire could have been used to clear woodland to create agricultural land or as a result of burnt mound activity. By c. $1690 \mathrm{BC}$, regeneration of woodland took place. Overall, changes to vegetation during the period of prehistoric mining/prospecting are not considered to be significant according to

477 the changepoint analysis (Figure 6).

478

The archaeological evidence clearly shows that people were present around Cors Fochno during the Bronze Age, which commences at approximately $324 \mathrm{~cm}$ in the pollen record. Several Bronze Age funerary and ritual sites, including the round barrows of Bedd Taliesin and Ynys Tudur, the Tre Taliesin standing stone and several burnt mounds, possibly Bronze Age, surround the bog (Page et al., 2012). A Bronze Age trough, made from oak, has also 
been dated to 1630-1380 BC and 1690-1430 BC (Page et al., 2012). A wattle walkway dated

485

486

487

488

489

490

491

492

493

494

495

496

497

498

499

500

501

502

503

504

505

506

507

to between $4000(321 \mathrm{~cm})$ and $3100(270 \mathrm{~cm}) \mathrm{BP}$, and human and animal fossilised footprints including cattle, sheep or goat and possibly a bear, that may date back to the Bronze Age, have been found in the peat at Borth and beach deposits at Ceredigion respectively. Consistent with these findings, both $\mathrm{rPb}$ and $\mathrm{rAs}$ point to increased metal deposition at Cors Fochno between c. 1500 and 1000 BC (Figure 7). Mighall et al (2009) reported a slightly different pattern with $\mathrm{Pb}$ and $\mathrm{Cu}$ increasing gradually from c. $1600 \mathrm{BC}$ to peak c. $485 \mathrm{BC}$ but both records suggest increased metal pollution at this time. At present there is no archaeological evidence for mining and smelting for this time period but As is contained within the mineral freibergite (which also contains $\mathrm{Cu}$ and it is intimately associated with galena), and is part of the local orefield. Arsenopyrite is also commonly associated with pyrite, galena, chalcopyrite and sphalerite and can be found on the fringes of the Snowdonia copper orefield and in the Central Wales orefield (Raybould, 1974; Bick, 1982). The only known operational copper mine in Wales during the mid-late Bronze Age was at Great Orme, Llandudno (Dutton et al., 1994).

Changepoint analysis suggests that a significant change occurred in vegetation at around $1000 \mathrm{BC}$, when more widespread soil erosion is also pointed out by the geochemical proxies, particularly reflected in CP3 (Figure 4). This marks the start of an increased and sustained deposition of more regional dusts and a phase of permanent woodland clearance surrounding Cors Fochno, seemingly unconnected to mining and/or smelting, during the late Bronze Age (from $279 \mathrm{~cm} 250 \mathrm{~cm}$; c. 1280 to 910 BC). Archaeological evidence confirms that people were present in the area during this time. A wooden trough, found on the southern margins of the bog at Llangynfelin, has been dated to $1210-1280$ Cal BC (Page et al., 2012) 
but confirmed Later Bronze Age settlements are still absent from Ceredigion (Driver, 2013).

509 Clearance may also have been associated with hillfort building in Wales during the Late

510 Bronze and Iron Ages (Driver, 2013). Iron Age hillforts and defended settlements are

511 common in west Wales, although these types of site are absent around Cors Fochno apart

512 from a small cropmark enclosure at Ynys Capel, which may be an Iron Age or medieval

513 enclosed settlement (Poucher, 2009; Page et al., 2012). A univallate hillfort was constructed

514 at Pen Dinas, Aberystwyth (Driver, 2013) and Middle to Late Iron Age dates have been

515 obtained from the main rampart at Darren hillfort (Timberlake, 2007). Increased population

516 in the lowlands may have also exerted greater pressure on land if upland areas were

517 abandoned as a result of climatic deterioration during the Late Bronze Age. However, there

518 is no noticeable change in the abundance of anthropogenic indicators in the Cors Fochno

519 pollen record to suggest that land use intensified at this time around the bog but tree cover

520 appears to have been in decline until (c. $600 \mathrm{BC}$ ) accompanied by a shift in Cp1 factor scores

521 and a lower LOI (Figures 3 and 4). A short-lived phase of woodland regeneration occurs

522 before clearance (predominantly hazel) is renewed in the Early Iron Age, c. 520 BC, which

523 continues into the Roman period. This pattern is consistent with renewed tree clearance at

524 Tregaron, c. $450 \mathrm{BC}$, and widespread clearance between the fifth to first centuries BC in

525 North Ceredigion with the development of multivallate hillforts in the last two centuries BC

526 (Driver, 2013).

527

528 During the late Bronze Age and Iron Age, the record of Cors Fochno atmospheric metal

529 pollution (Figure 7) suggests a diverse use of metals: rPb is elevated between c. 710-550 BC,

530 rZn between c. 540-350 BC, rPb and rAs by c. 230 BC, and rZn and rAs by c. 30 BC. Whether

531 this represents pollution generated from local metal extraction or metallurgy is still 
contestable as there is a lack of local Iron Age archaeological evidence for lead working

533 although the geochemical evidence is consistent with the previous lead record from the

534 same site (Mighall et al., 2009). This compares favourably with evidence from elsewhere in

535 Britain and Europe concerning the possible rise of a lead mining/metallurgical industry

536 during the Late Iron Age, which culminated in the Roman period (e.g. Renberg et al., 2001;

537 De Vleeschouwer et al. 2010). This includes sites in the British Isles: north-west and south

538 west England (Le Roux et al. 2004; Meharg et. al., 2012), central Wales (Mighall et al.,

539 2002b), at Flanders Moss in central Scotland (Cloy et al., 2005, 2008) and Raeburn Flow in

540 southern Scotland (Küttner et al., 2014). Changepoint analysis suggests that a significant

541 change in vegetation occurred c. 500 BC, seemingly unassociated with mining or metallurgy,

542 but coincident with a large, permanent decline of Corylus. A change in land use might have

543 been responsible with Plantago lanceolata recorded more regularly with higher percentages

544 and a gradual rise in Poaceae. Cereal-type pollen was recorded intermittently. LOI values

545 decreased and the Cp1 scores showed a slight gradual increase during this period of

546 deforestation, both indicative of soil erosion (Figures 3, 4). This trend is also apparent in the

547 concentrations of the individual elements (e.g. Rb and to a lesser extent, $\mathrm{Al}, \mathrm{Si}$ and Ti;

548 Supplementary Figure 2a). At a more regional scale, soil erosion remains high although

549 possibly by shifting in area, as suggested by the see-saw pattern in $\mathrm{Cp} 3$ scores (Figure 4).

550

551 The Romans invaded Wales between AD 43 and AD 78 (Moore, 1968) and apparently

552 accelerated the clearance of woodland that had commenced much earlier (see above).

553 Several Roman forts were established in Ceredigion (Driver, 2013). A $1^{\text {st }}$ century AD smelting

554 complex was operational on the fringe of the Cors Fochno approximately 500 metres from

555 the Flavin period Roman Fort (Timberlake, 2006; Page et al., 2012; Figure 1). The five dates 

from the industrial waste range from $90 \mathrm{BC}$ through to $A D 240$, all overlapping between cal. AD 50-90 (Page et al., 2012) which is consistent with the radiocarbon dated $\mathrm{Pb}$ pollution at

558 Cors Fochno reported by Mighall et al. (2009), lead enrichment in another core from the bog dated to between $110 \mathrm{BC}$ to $A D 180$ (Page et al., 2012) and the peak in rPb recorded at c. AD 40 and 100 in this study. It is likely that lead smelting began in the late prehistoric period and continued until the early/mid-second century AD. From c. AD 74 through to AD 120-140 production may have been entirely under Roman military control (Page et al., 2012). If lead smelting did take place from c. $420 \mathrm{BC}$ through the early part of the Roman occupation (until c. AD 140), it took place during a period of relatively rapid clearance of hazel woodland/scrub and more widespread clearance from c. 145 BC, followed by a phase of rapid woodland regeneration from $c . A D 210$. Changes in vegetation at this time are identified as significant in the changepoint analysis with spikes at c. AD 0 and AD 200 framing the decline and recovery of woodland (Figure 6). Charcoal recovered from the smelting site was dominated by oak although the results suggest that a wide range of species were used from the surrounding area as fuel, including Betula spp., Corylus avellana and Alnus glutinosa (Page et al., 2012). The use of local wood as a fuel is attested by the palaeoenvironmental analysis, which records a reduction in oak, alder and hazel in both Caseldine's pollen diagrams (in Page et al., 2012) and this study (LPAZ CF4). Woodland clearance during the first part of the Roman occupation resulted in increased soil erosion at both local and regional scales, as attested by peaking $\mathrm{Cp} 1$ and $\mathrm{Cp} 3$ scores (Figure 4).

Woodland regeneration continued into medieval times and a similar pattern is observed at other sites across Wales (see Moore, 1968; Page et al., 2012). A recovery of tree and shrub percentages can be seen in other pollen diagrams from Cors Fochno as well (Figure 5a; LPAZ 
581 decommissioned between AD 130 and 170. An increase in oak and alder, concomitant with

582 a decline in taxa associated with agriculture, characterised the late Roman period (Hughes

583 et al., 2007). Woodland cover remained relatively stable at Cors Fochno as total arboreal

584 pollen percentages fluctuated around 40\% TLP into the early medieval period. Local soil erosion was low for most of this phase but sharply increased at the end ( $C p 1$, Figure 4). The opposite seems to have occurred at a regional scale, as erosion remained high until c. AD 1000 and then suddenly decreased (Cp3, Figure 4).

588

Radiocarbon determinations and dendrochronological dates show that the timber trackway placed across part of Cors Fochno was constructed in the early- to mid-eleventh century AD with timbers replaced up to or soon after AD 1136 (Page et al., 2012). The final major phase of woodland clearance (end of LPAZ CF5, start of LPAZ CF6) broadly coincides with the

593 Cistercian Strata Florida Abbey which was founded in AD 1165 until its dissolution by Henry VIII between AD 1536 and 1540. Increased dust deposition on to the bog surface is suggested by the high Cp1 scores (c. AD 1160-1420) and an initial decrease in LOI percentages (Figure 3). The shift in the $\mathrm{Cp} 3$ scores suggests the dust is mostly derived from

597 local sources with a higher felsic component (Figure 4). Changes in vegetation at this time are identified as significant (Figure 6; c. AD 1200 \& 1375). From c. AD 1145 onwards tree and shrub pollen percentages decline rapidly until c. AD 1380 and then more gradually. Edward I

600 also ordered that all woodland be cleared in AD 1280 to remove safe havens for thieves and

601 rebels (Moore, 1968). As a consequence, Moore (1968) suggests that these instructions

602 may well have prompted the demise of alder in valley and lowland woods: Alnus pollen

603 declines at Cors Fochno at this time. Direct archaeological evidence for occupation and 
exploitation in the area surrounding the bog is scarce after the Romans (Page et al., 2012).

Page et al. (2012: 290) suggest that Llangynfelin parish church originated in the early medieval period and that a church was established by the fourteenth century, as were several small settlements, the occupants of which were probably engaged in agriculture and small-scale metal mining. By AD 1375, there was an increase in lead deposition and therefore the changes in vegetation, regarded as significant, can be linked to mining and

610 metallurgy as well as an intensification of agriculture.

611

612 The total arboreal pollen percentage reached its lowest point for four millennia at c. AD $6131900(10 \mathrm{~cm})$ implying widespread clearance until the planting of commercial forestry over

614 the last 100 years. The rise in cereal-type pollen towards the end of LPAZ 5 is consistent with

615 the increased importance of agriculture from the construction of the Abbey and culminating

616 during the Napoleonic wars (1799-1815) (Moore, 1968). The Cp1 and Cp3 scores suggest

617 that atmospheric dust deposition into the bog was at its highest level in the first half of the 618 AD 20 $0^{\text {th }}$ century (Figure 4).

6.2: Towards a model for the environmental impact of mining and metallurgy: Pollen records

621 close to Bronze Age copper mines in Wales and Ireland indicate that woodland disturbance was small-scale and non-permanent (Mighall \& Chambers, 1993; Mighall et al., 2000; 2004; 2010; 2012), characteristics also shared with prehistoric ironworking sites (Chambers and 624 Lageard, 1993; Mighall and Chambers, 1997). At Cors Fochno, the pattern of tree pollen is 625 slightly different. Notwithstanding the occasional reversal, total tree pollen percentages 626 continued to decline between c. 1900 and 1700 BC. Clear impacts are recorded on individual 627 taxa. This might be because the Cors Fochno pollen data represents a regional record and it 
could be the result of woodland exploitation associated with numerous mines and/or

629 prospecting sites (Timberlake, 2009). Woodland does recover to pre-mining levels (based on

630 pollen percentages) and this evidence is consistent with the idea that mining and

631 metallurgical activities in Bronze Age Britain and Ireland did not have a significant or long-

632 lasting impact on woodland cover (Mighall et al., 2004; 2010; 2012). In the mining region of

633 Falkenstein, near Schwaz in the Tyrol, Austria, Breitenlechner et al. (2010) also suggested

634 prehistoric copper mining did not lead to large scale deforestation. At Kitzbühel, two

635 episodes of forest clearance coincided with increasing heavy metal values but the forest

636 regenerated thereafter (Viehweider et al. 2015). Hints of Early Bronze Age mining at

637 Brixlegg do not seem to be of sufficient intensity to register in the pollen diagram but later

638 mining in the Late Bronze Age caused small clearances and adversely affected the most

639 abundant trees, but once mining activities cease there is some evidence for forest

640 regeneration (Breitenlechner et al., 2013). Jouffroy-Bapicot et al. (2007) suggest that

641 selective forest clearance and metallurgic contamination caused by local mining is closely

642 connected at sites in the Massif Central and Basque Country but here too woodland

643 regenerated. At Morvan (Massif Central) metallurgic activity during the Mid-Bronze Age led

644 to modifications in plant cover but total percentages of arboreal pollen were not

645 dramatically altered. Similar observations are made based on pollen records at Mont Lozère

646 (Massif Central) and Quinto Real in the Basque Country, where tree taxa percentages

647 decline associated with a concomitant increase in lead concentrations during the Bronze

648 and Iron Ages. As pressure from metallurgical activities diminished (reflected by a decrease

649 in $\mathrm{Pb}$ ), total arboreal taxa recover to values similar to those recorded although forest

650 composition was modified. Whilst Fagus was exploited for ore smelting in prehistory in 

but rather episodic declines of beech.

653

654 Another possible diagnostic indicator of prehistoric mining is evidence of firesetting.

655 Firesetting could be represented in the palaeoecological record by increased values of 656 microscopic charcoal. Assuming the tree clearance was primarily driven by mining, the

657 peaks in microscopic charcoal recorded at Cors Fochno during the Bronze Age could also be 658 associated with firesetting as they correlate with the dates of known prehistoric mines in 659 the vicinity of the bog (Figure 6; LPAZ CF1b) but the scale of mining at this time was small660 scale and akin to prospecting. Pyrophytic taxa such as Calluna and Pteridium do not show an 661 immediate response suggesting that the charcoal was not derived from natural fires on the 662 bog surface. The presence of cereal-type pollen and a suite of non-arboreal taxa often associated with pasture and disturbed ground suggest that land was also cultivated and

664 used for pasture so the use of fire to clear woodland could have produced the increases in the microscopic charcoal. The evidence elsewhere is also circumspect. At Copa Hill

666 microscopic charcoal only peaks towards the end of the presumed period of prehistoric

667 mining (Mighall \& Chambers, 1993). Because the pattern of microscopic charcoal records is 668 very variable in palaeoenvironmental archives during the known periods of prehistoric 669 mining, it may not be a reliable indicator of firesetting.

670

671 Woodland clearance re-commenced during the late Iron Age corresponding with renewed

672 atmospheric pollution both of which culminated in Roman times, as has been identified at

673 numerous sites in Britain and Europe (see references herein). These impacts were normally

674 larger in scale compared to the Bronze Age but were also non-permanent with woodland 
675 regeneration often occurring as the Roman Empire collapsed. The evidence from Cors

676 Fochno follows this pattern. However, there are slight differences. Forest clearance took

677 much longer to recover (and not to pre-Roman values based on the pollen record) and

678 forests were permanently modified in Morvan (Jouffroy-Bapicot et al., 2007). In contrast, at

679 La Molina in NW Iberia, the impact on vegetation appears to be more similar to that

680 described for prehistoric times with a series of short-lived declines in woodland followed by

681 regeneration (López-Merino et al., 2014). Forest clearance was detected during Roman

682 times and considered not to be associated with mining as heavy metal concentrations did

683 not increase in tandem with decreased arboreal pollen at Kitzbühel and at Brixlegg

684 (Breitenlechner et al., 2013; Viehweider et al., 2015).

685

686 Whilst forest cover showed a degree of resilience during the earliest phases of mining and

687 metallurgy, selective deforestation and possible selectivity of trees for specific purposes and

688 changes to the composition of woodland has often been suggested (e.g. the use of pine at

689 the Bronze Age Mount Gabriel copper mines; O’Brien, 1990). Although in some cases

690 selectivity is evident in the archaeological and palaeoecological record, the choice of wood

691 for industrial use seems to predominantly reflect local availability and woodland

692 composition (e.g. Mighall and Chambers, 1993, 2000). This is also observed at Cors Fochno

693 and other sites analysed in Wales. Similar observations have been made in mining regions

694 across Europe. The exploitation of Fagus appears to have been preferentially selected but it

695 was the dominant tree in the forest surrounding Morvan and at Mont Lozère (Jouffroy-

696 Bapicot et al., 2007) and in Southern Bavaria, Germany (Küster \& Rehfuess, 1997). Quercus

697 was favoured for charcoal production in the High Aldudes valley (Galop et al., 2001). Overall

698 forest cover was maintained or recovered at all the sites. Similar examples also occur for 
699 ferrous sites in prehistory (e.g. Mighall and Chambers, 1997) and during Medieval times

700 (Crew \& Mighall, 2013). Exploitation of the dominant trees in forests and woodlands,

701 whether preferentially or not, also altered their composition. Examples are mainly seen in

702 Europe including the mining regions of Austria (Breitenlechner et al., 2010, 2013;

703 Viehweider et al., 2015) France and the Basque Country (Jouffroy-Bapicot et al., 2007).

704 Changes in woodland composition are less obvious at Cors Fochno and Copa Hill in Wales, in

705 the Northern Pennines (Mighall et al, 2004) and Mount Gabriel in Ireland (Mighall \&

706 Chambers, 1993; Mighall et al., 2000).

707

708

\section{Conclusions}

1. At Cors Fochno, changepoint analysis suggests prehistoric mining and/or metallurgical activities did not appear to have a significant impact on vegetation. This could be because the sites surrounding the bog were examined by prospectors rather than mined on any significant scale. Further sites need to be analysed to see if this is typical.

2. The conceptual model of small-scale, non-permanent impacts on vegetation at times of prehistoric mining appears to be consistent across regions with evidence of early mining and metallurgy. If the impact on woodland had greater longevity, once activities ceased woodlands still recovered.

3. In contrast, changes in vegetation at Cors Fochno during Roman times were significant, particularly woodland clearance, and coincided with increased metal deposition on the bog. Any decrease that occurred during an episode of prehistoric and/or Roman mining/metallurgy was followed by regeneration when activities ceased, although woodland recovery is also seen in non-mining areas as well. The 
Roman period is the first time that mining and metallurgy appears to have had a significant impact on vegetation surrounding Cors Fochno. In contrast, the results from La Molinia (NW Spain), for example, show a slightly different pattern in the pollen record, and more fine resolution studies could provide even further insights into the relationship between early mining and metallurgy and its impact on vegetation.

4. Overall, the results indicate that woodland/forest cover had a degree of resilience to mining and metallurgy in terms of total cover but there are examples whereby the some selectivity of trees seems to have taken place. There is evidence to suggest mining or prospection.

\section{Acknowledgements}

741 Toby Driver kindly provided information about the archaeology of the region. Jenny Johnson

742 and Jamie Bowie drew the figures. Ed Schofield commented upon on an earlier draft of the manuscript. Permission to core Cors Fochno was provided by Mike Bailey (CCW). This project was funded by The Leverhulme Trust, grant number F/00/732/C and support from

745 Cambria Archaeology. The comments from two reviewers helped to improve the manuscript. 


\section{References}

749 Appleby, P.G. and Oldfield, F., 1978. The calculation of lead-210 dates assuming a constant rate of supply of unsupported $210 \mathrm{~Pb}$ to the sediment. Catena $5,1-8$.

751

752

Barber, K.E., 1976. History of vegetation. Methods in Plant Ecology, 5, p.83.

753

754

Bick, D.E., 1982. The Old Copper Mines of Snowdonia. Newent: Pound House.

755

756

Bindler, R., Segerström, U., Pettersson-Jensen, M., Berg, A., Hansson, S., Holmström, H.,

Olsson, K. and Renberg, I., 2011. Early medieval origins of iron mining and settlement in

758

central Sweden: multiproxy analysis of sediment and peat records from the Norberg mining

759 district. J. Archaeol. Sci. 38, 291-300.

760

761

Birks, H.J.B. and Birks, H.H., 1980. Quaternary Palaeoecology. London: Edward Arnold.

762

763

Blaauw, M. 2010. Methods and code for 'classical' age-modelling of radiocarbon sequences.

764

Quat. Geochron. 5, 512-518.

765

766 Breitenlechner E., Hilber M., Lutz J., Kathrein Y., Unterkircher A. and Oeggl K. 2010. The impact of mining activities on the environment reflected by pollen, charcoal and geochemical analyses. J. Archaeol. Sci. 37, 1458-1467. 
771 Study on the Environmental Reflection of Prehistoric Mining Activities at the Mitterberg

772 Main Lode (Salzburg, Austria). Archaeometry 56, 102-128.

773

774 Brown A.G., Carpenter, R.G., Walling, D.E. 2007. Monitoring fluvial pollen transport, its relationship to catchment vegetation and implications for palaeoenvironmental studies.

776 Rev. Palaeobot. Palynol. 147, 60-76.

777

778

Bunting, M.J. 2003. Pollen-vegetation relationships in non-arboreal moorland taxa. Rev.

Palaeobot. Palynol. 125, 285-298.

780

781

Chambers, F.M. and Lageard, J.G.A., 1993. Vegetational history and environmental setting of

Crawcwellt, Gwynedd. Archaeol. Wales 33, 23-25.

783

784

Charman, D. J., Blundell, A., Chiverrell, R. C., Hendon, D. and Langdon, P. G. 2006.

Compilation of non-annually resolved Holocene proxy climate records: stacked Holocene

786 peatland palaeo-water table reconstructions from northern Britain. Quat. Sci. Rev. 25, 336350.

788

Cheburkin, A.K. and Shotyk, W., 1996. An energy-dispersive miniprobe multielement analyzer (EMMA) for direct analysis of $\mathrm{Pb}$ and other trace elements in peats. Fresenius $\mathrm{J}$. 
794 of antimony and lead profiles over the past 2500 years in Flanders Moss ombrotrophic peat 795 bog, Scotland. J. Environ. Monit. 7, 1137-1147.

796

797 Cloy, J.M., Farmer, J.G., Graham, M.C., MacKenzie, A.B. and Cook, G.T., 2008. Historical 798 records of atmospheric $\mathrm{Pb}$ deposition in four Scottish ombrotrophic peat bogs: an isotopic comparison with other records from western Europe and Greenland. Global Biogeochemical Cycles 22, GB2016, doi:10.1029/2007GB003059.

801

802

Crew, P. \& Mighall, T.M. 2013. The fuel supply and woodland management at a $14^{\text {th }}$ century bloomery in Snowdonia, a multi-disciplinary approach. In Humphris, J. \& Rehren, T. (eds) The World of Iron. London: Archetype Publications, 473-482.

805

806 De Vleeschouwer, F., Le Roux, G. and Shotyk, W., 2010. Peat as an archive of atmospheric 807 pollution and environmental change: A case study of lead in Europe. PAGES Magazine, 18, $808 \quad 20-22$.

809

810 Driver, T. 2013. Architecture, Regional Identity and Power in the Iron Age Landscapes of 811 Mid Wales. The Hillforts of North Ceredigion. BAR 583. Oxford: Archaeopress.

812

813 Dutton, A., Fasham, P.J., Jenkins, D.A., Caseldine, A.E. and Hamilton-Dyer, S. 1994.

814 Prehistoric Copper Mining on the Great Orme, Llandudno, Gwynedd. Proc. Prehist. Soc. 60, $815 \quad 245-286$.

816 
817 Edwards, K.J., 1981. The separation of Corylus and Myrica pollen in modern and fossil

818 samples. Pollen Spores 23, 205-218.

819

820 Eriksson, L., 1999. Introduction to multi-and megavariate data analysis using projection

821 methods (PCA \& PLS). Umetrics AB.

822

823 Fægri K., Kaland P.E., Krzywinski K. 1989. Textbook of Pollen Analysis, fourth ed. John Wiley

824

\& Sons, Chichester.

825

826 Foster, I.D.L, Boardman, J., Keay-Bright, J., Meadows, M.E. 2005. Land degradation and

827 sediment dynamics in the South African Karoo. International Association of Hydrological

828 Sciences Publication 292, 207-213.

829

830 Galop, D., Tual, M., Monna, F., Dominik, J., Beyrie, A. and Marembert, F., 2001. Cinq

831 millénaires de métallurgie en montagne basque. Les apports d'une démarche intégrée

832 alliant palynologie et géochimie isotopique du plomb. Sud-Ouest Européen 11, 3-15.

833

834 Gallagher, K., Bodin, T., Sambridge, M., Weiss, D., Kylander, M. and Large, D., 2011.

835 Inference of abrupt changes in noisy geochemical records using transdimensional

836 changepoint models. Earth. Planet. Sci. Lett. 311(1), 182-194.

837

838 García-Alix, A., Jimenez-Espejo, F.J., Lozano, J.A., Jiménez-Moreno, G., Martinez-Ruiz, F.,

839 Sanjuan, L.G., Jimenez, G.A., Alfonso, E.G., Ruiz-Puertas, G. and Anderson, R.S., 2013. 
840 Anthropogenic impact and lead pollution throughout the Holocene in Southern Iberia. Sci.

841 Tot. Environ. 449, 451-460.

842

843 Godwin, H., 1943. Coastal peat beds of the British Isles and North Sea: presidential address

844 to the British Ecological Society 1943. J. Ecol. 31, 199-247.

845

846 Godwin, H. and Newton, L., 1938. The submerged forest at Borth and Ynyslas, Cardiganshire.

847 New. Phytol. 37, 333-344.

848

849 Grimm, E.C. 1987. CONISS: A Fortran 77 program for stratigraphically constrained cluster

850 analysis by the method of incremental sum of squares. Comput. Geosci. 13, 13-35.

851

852 Grimm, E.C. 2004. TGView 2.0.2. Illinois State Museum.

853

854

Hansson, S.V., Rydberg, J., Kylander, M., Gallagher, K. and Bindler, R., 2013. Evaluating

855

paleoproxies for peat decomposition and their relationship to peat geochemistry. Holocene

856

23, 1666-1671.

857

858

Howells M.F. 2007. Wales. British Regional Geology. Nottingham: BGS.

859

860 Hughes, P.D.M., Lomas-Clarke, S.H., Schulz, J., Jones, P. 2007. The declining quality of late-

861 Holocene ombrotrophic communities and the loss of Sphagnum austinii (Sull. Ex Aust.) on

862 raised bogs in Wales. Holocene 17, 613-625.

863 
Hughes, P.D.M. and Schulz, J., 2001. The development of the Borth Bog (Cors Fochno) mire system and the submerged forest beds at Ynyslas. In: Walker, M.J.C. and McCarroll, D. (Eds)

866 The Quaternary of West Wales. QRA Field Guide. QRA, London, 104-112.

867

868 Innes, J., Blackford, J. and Chambers, F., 2006. Kretzschmaria deusta and the northwest European mid-Holocene Ulmus decline at Moel y Gerddi, north Wales, United Kingdom.

$870 \quad$ Palynol. 30, 121-132.

871

872 Jouffroy-Bapicot I., Pulido, M., Baron, S., Galop, D. Monna, F., Lavoie M., Ploquin A., Petit C., 873 De Beaulieu J-L., Richard, H. 2007. Environmental impact of early palaeometallurgy: pollen 874 and geochemical analysis. Veg. Hist. Archaeobot. 16, 251-258.

875

876

Küster, H. and Rehfuess, K.E., 1997. Pb and Cd concentrations in a southern Bavarian bog 877 profile and the history of vegetation as recorded by pollen analysis. Water Air Soil Pollut.

878 $100,379-386$.

879

880

Küttner, A., Mighall T.M., De Vleeschouwer F., Mauquoy D., Martínez Cortizas, A., Foster, 881 I.D.L., Krupp E. 2014. A 3300-year atmospheric metal contamination record from Raeburn 882 Flow raised bog, south west Scotland. J. Archaeol. Sci. 44, 1-11.

883

884

Kylander, M.E., Weiss, D.J., Cortizas, A.M., Spiro, B., Garcia-Sanchez, R. and Coles, B.J., 2005. year old peat core from NW Spain. Earth. Planet. Sci. Lett. 240, 467-485. 

novel geochemical approach to palaeorecords of dust deposition and effective humidity:

8908500 years of peat accumulation at Store Mosse (the "Great Bog"), Sweden. Quat. Sci. Rev. $69,69-82$.

892

Le Roux, G., Weiss, D., Grattan, J., Givelet, N., Krachler, M., Cheburkin, A., Rausch, N., Kober, atmospheric lead pollution in England using a peat profile from Lindow bog, Manchester. J. Environ. Monit. 6, 502-510.

897

López-Merino, L., Martínez Cortizas, A., Reher, G.S., López-Sáez, J.A., Mighall, T.M., Bindler, landscape for the last 2500 years. J. Archaeol. Sci. 50, 208-218.

901

Marshall, P. D., O'Hara, S. L., \& Ottaway, B. S. 1999. Early copper metallurgy in Austria and methods of assessing its impact on the environment. Der Anschnitt 9, 255-266.

904

Martínez Cortizas A., López-Merino, L., Mighall, T.M., Bindler, R., Kylander, M. 2016. Early atmospheric metal pollution provides evidence for Chalcolithic/Bronze Age mining and metallurgy in south west Europe. Sci. Tot. Environ. 545-546, 398-406.

908

909 Mauquoy, D., Yeloff, D., Van Geel, B., Charman, D. J., Blundell, A. 2008. Two decadally

910 resolved records from north-west European peat bogs show rapid climate changes

911 associated with solar variability during the mid-late Holocene. J. Quat. Sci. 23, 745-763. 
913 Meharg, A.A., Edwards, K.J., Schofield, J.E., Raab, A., Feldmann, J., Moran, A., Bryant, C.L.,

914 Thornton, B. and Dawson, J.J., 2012. First comprehensive peat depositional records for tin,

915 lead and copper associated with the antiquity of Europe's largest cassiterite deposits. J.

916 Archaeol. Sci. 39, 717-727.

917

918 Mighall, T.M. and Chambers, F.M. 1993: The environmental impact of prehistoric copper

919 mining at Copa Hill, Cwmystwyth, Wales. Holocene 3, 260-264.

920

921

Mighall, T.M. and Chambers, F.M. 1997: Early ironworking and its impact on the environment: palaeoecological evidence from Bryn y Castell Hillfort, Snowdonia, north Wales. Proc. Prehist. Soc. 63, 199-219.

924

925

Mighall, T.M., Chambers, F.M., Lanting, J. and O’Brien, W.F. 2000: Prehistoric copper mining and its impact on vegetation: palaeoecological evidence from Mount Gabriel, Co. Cork, southwest Ireland. In Nicholson, R.A. and O'Connor, T.P. (eds) Prehistoric People as Agents of Environmental Change. Oxford: Oxbow, 19-29.

929

930 Mighall, T.M., Abrahams, P.W., Grattan, J.P., Hayes, D., Timberlake, S. and Forsyth, S.,

931 2002a. Geochemical evidence for atmospheric pollution derived from prehistoric copper

932 mining at Copa Hill, Cwmystwyth, mid-Wales, UK. Sci. Tot. Environ. 292, 69-80. 

pollution history for Pb-Zn mining in the Ystwyth Valley, Dyfed, mid-Wales, UK. Geochem.: Explor. Environ. Anal. 2, 175-184.

937

Mighall, T.M., Dumayne-Peaty, L. and Cranstone, D. 2004: A record of atmospheric pollution and vegetation change as recorded in three peat bogs from the Northern Pennines $\mathrm{Pb}-\mathrm{Zn}$ orefield. Environ. Archaeol. 9, 13-38.

941

942

Mighall, T.M., Timberlake, S., Foster, I.D.L., Krupp, E. \& Singh, S. 2009. Ancient copper and lead pollution records from a raised bog complex in Central Wales, UK. J. Archaeol. Sci. 36, 7, 1504-1515.

945

Mighall, T.M., Timberlake, S., Crew, P. 2010. Vegetation changes in former mining and metalworking areas of Wales and Ireland during prehistoric and medieval times. In: Belford, P, Palmer, M and White, R. (Eds) Footprints of Industry. BAR British Series 523, 19-26. vegetation changes in former mining and metalworking areas during prehistoric and Roman times. Notizie Archeologiche Bergomensi 20, 117-130.

953

954 Monna, F., Petit, C., Guillaumet, J.P., Jouffroy-Bapicot, I., Blanchot, C., Dominik, J., Losno, R., 955 Richard, H., Lévêque, J. and Château, C., 2004. History and environmental impact of mining 956 activity in Celtic Aeduan territory recorded in a peat bog (Morvan, France). Environ. Sci. 957 Technol. 38, 665-673. 
959 Moore, P. D. 1968. Human influence upon vegetational history in North Cardiganshire.

$960 \quad$ Nature 217, 1006-1009.

961

962 Moore P.D., Webb J.A., Collinson, M.E. 1991. Pollen Analysis. Oxford, Blackwell Science.

963

964 Myrstener, E., Lidberg, W., Segerström, U., Biester, H., Damell, D., \& Bindler, R. 2016. Was

965 Moshyttan the earliest iron blast furnace in Sweden? The sediment record as an

966 archaeological toolbox. J. Archaeol. Sci. Reports 5, 35-44.

967

968 O'Brien, W.F., 1990. Prehistoric Copper Mining in South-West Ireland: The Mount Gabriel969 Type Mines. Proc. Prehist. Soc. 56, 269-290.

970

971 Page, N., Hughes, G, Jones, R. and Murphy, K. 2012. Excavations at Erglodd, Llangynfelin,

972 Ceredigion: prehistoric/Roman lead smelting site and medieval trackway. Archaeol.

973 Cambrensis 161, 285-356.

974

975 Pompeani, D.P., Abbott, M.B., Steinman, B.A. and Bain, D.J. 2013. Lake sediments record 976 prehistoric lead pollution related to early copper production in North America. Environ.

977 Sci.Technol. 47, 5545-5552.

978

979 Pontevedra-Pombal, X., Mighall, T.M., Nóvoa-Muñoz, J.C., Peiteado-Varela, E., Rodríguez-

980 Racedo, J., García-Rodeja, E. and Martínez-Cortizas, A., 2013. Five thousand years of 
atmospheric $\mathrm{Ni}, \mathrm{Zn}, \mathrm{As}$, and Cd deposition recorded in bogs from NW Iberia: prehistoric and historic anthropogenic contributions. J. Archaeol. Sci. 40, 764-777.

983

Poucher, P. 2009. The archaeological potential of Ceredigion's wetlands: Cors Fochno.

Archaeol. Wales 49, 62-64.

986

987

Pyatt, F.B., Gilmore, G., Grattan, J.P., Hunt, C.O. and Mclaren, S., 2000. An imperial legacy?

An exploration of the environmental impact of ancient metal mining and smelting in

989

southern Jordan. J. Archaeol. Sci. 27, 771-778.

990

991

Raybould, J.G., 1974. Ore textures, paragenesis and zoning in the lead-zinc veins of mid-

992

Wales. Trans. Inst. Min. Metall., Sect. B, 83, B112-B119.

993

994

Reille, M. 1999. Pollen et spores d'Europe et d'Afrique du nord ( $2^{\text {nd }}$ edn.) Laboratoire de

995

Botanique Historique et Palynologie, Marseille.

996

997 Reimer, P.J., Baillie, M.G.L., Bard, E., Bayliss, A., Beck, J.W., Bertrand, C., Blackwell, P.G.,

998 Buck, C.E., Burr, G., Cutler, K.B., Damon, P.E., Edwards, R.L., Fairbanks, R.L., Freidrich, M.,

999 Guilderson, T.P., Hughen, K.A., Kromer, B., McCormac, F.G., Manning, S., Bronk Ramsey, C.,

1000 Reimer, R.W., Remmele, S., Southon, J.R., Stuiver, M., Talamo, S., Taylor, F.W., van der

1001 Plicht, J., Weyhenmeyer, C.E. 2009. Quaternary Isotope Laboratory, Radiocarbon Calibration

1002 Program, University of Washington. http://radiocarbon.pa.qub.ac.uk/calib/calib.html 
Reimer, P.J., Bard, E. Bayliss, A. Beck, J.W. Blackwell, P.G. Ramsey, C.B. Buck, C.E., Cheng, H.,

1005 Edwards, R.L., Friedrich, M and Grootes, P.M. 2013. IntCal13 and Marine13 radiocarbon age

1006 calibration curves 0-50,000 years cal BP. Radiocarbon 55, 1869-1887.

1007

1008 Renberg, I., Bindler, R. and Brännvall, M.L., 2001. Using the historical atmospheric lead-

1009 deposition record as a chronological marker in sediment deposits in Europe. Holocene, 11,

$1010 \quad 511-516$.

1011

1012 Schulte, E.E. and Hopkins, B.G., 1996. Estimation of soil organic matter by weight loss-on-

1013 ignition. Soil organic matter: Analysis and interpretation, 21-31.

1014

1015 Silva-Sánchez, N., Cortizas, A.M. and López-Merino, L., 2014. Linking forest cover, soil

1016 erosion and mire hydrology to late-Holocene human activity and climate in NW Spain.

1017 Holocene 24, 714-725.

1018

1019 Silva-Sánchez, N. 2015. Mining and Metallurgical activities in N Iberia and their link to forest

1020 evolution using environmental archives (Centuries AD V to XI). Estudos do Quaternário 12:

$1021 \quad 15-26$.

1022

1023 Stace, C. 2001. New flora of the British Isles ( $2^{\text {nd }}$ edn.) Cambridge University Press,

1024 Cambridge.

1025

1026 Stockmarr, J. 1971. Tablets with spores used in absolute pollen analysis. Pollen Spores 13,

$1027 \quad 615-621$. 
1029 Timberlake, S., 1995a. Llancynfelin mine, Llancynfelin. Archaeol. Wales 35, 42-43.

1030

1031 Timberlake, S., 1995b. Nantyrarian mine, Melindwr. Archaeol. Wales 35, 43-45.

1032

1033 Timberlake, S., 1996a. Tyn y Fron mine, Cwm Rheidol, Ceredigion. Archaeol. Wales 36, 61-

103462.

1035

1036 Timberlake, S., 2003a. Excavations on Copa Hill, Cwmystwyth (1986-1999). BAR British

1037 Series 348.

1038

1039 Timberlake, S. 2003b. Early Mining research in Britain: the developments of the last ten

1040 years. In: Craddock, P., Lang, J. (Eds) Mining and Metal Production through the Ages.

1041 London: The British Museum Press, 21-42.

1042

1043 Timberlake, S., 2006. Excavations of early mine working at Twll y mwyn (Cwm Darren) and 1044 Erglodd, Ceredigion. Archaeol. Wales, 46, pp.79-86.

1045

1046 Timberlake, S. 2007. The use of experimental archaeology/archaeometallurgy for the 1047 understanding and reconstruction of Early Bronze Age mining and smelting technologies. In 1048 La Niece, S., Hook, D. \& Craddock, P. (eds) Metals and Mining: Studies in Archaeometallurgy, 1049 Archetype Publications in association with The British Museum p27-36.

1051 Timberlake, S. 2009. The Origins of Metal Mining in Britain -the explorations and 
1052 archaeological excavations of the Early Mines Research Group in Central Wales. In Linton,

1053 D.J. (ed.) The Lode of History, Proceedings of the Welsh Mines Society Conference 2007,

1054 Welsh Mines and Mining No.1, 3-16.

1055

1056 van Geel, B. 1978. A palaeoecological study of Holocene peat bog sections in Germany and 1057 the Netherlands. Rev. Palaeobot. Palynol. 25, 1-120.

1058

1059

van Geel B. 2005. Non pollen palynomorphs. In: Smol JP, Birks, HJB, Last WM. (Eds).

1060 Tracking environmental change using lake sediments. Kluwer Academic Publications,

1061 Dordrecht, pp. 99-119.

1062

1063 van Geel, B., Hallewas, D.P., Pals J.P. 1982/1983. A late Holocene deposit under the

1064 Westfriese Zeedijk near Enkhuizen (Prov. Of Noord-Holland, The Netherlands):

1065 palaeoecological and archaeological aspects. Rev. Palaeobot. Palynol. 38, 269-335.

1066

1067 van Geel, B., Aptroot, A., Mauquoy, D. 2006. Sub-fossil evidence for fungal hyperparasitism

1068 (Isthmospora spinosa on Meliola ellisii, on Calluna vulgaris) in a Holocene intermediate

1069 ombrotrophic bog in northern-England. Rev. Palaeobot. Palynol. 141, 121-126.

1070

1071 van Geel, B., Buurman, J., Brinkkemper, O., Schelvis, J., Aptroot, A., van Reenen, G., Hakbijl

1072 T. 2003. Environmental reconstruction of a Roman Period settlement site in Uitgeest (The

1073 Netherlands), with special reference to coprophilous fungi. J. Archaeol. Sci. 30, 873-883.

1074 
1075 Viehweider, B., Lutz, J. and Oeggl, K. 2015. Late-Holocene land use changes caused by

1076 exploitation in the mining region of Kitzbühel (Tyrol, Austria). Veg. Hist. Archaeobot. 24,

$1077 \quad 711-729$.

1078

1079 Weiss, D., Shotyk, W., Cheburkin, A.K. and Gloor, M., 1998. Determination of Pb in the ash

1080 fraction of plants and peats using the Energy-dispersive Miniprobe Multielement Analyser

1081 (EMMA). Analyst 123, 2097-2102.

1082

1083 Yeloff, D., Charman, D., van Geel, B. and Mauquoy, D., 2007. Reconstruction of hydrology,

1084 vegetation and past climate change in bogs using fungal microfossils. Rev. Palaeobot.

1085 Palynol. 146, 102-145.

1086

1087 Figure captions

1088 Figure 1: Location of the study area of Cors Fochno (Borth Bog), North West Wales, showing

1089 A. Location in the UK; B. detailed map of the Erglodd mine and Roman lead smelting site; C.

1090 the location of the sampling site and mining archaeology.

1091

1092 Figure 2: Age-depth curve for the Cors Fochno core. Model constructed in Clam using a

1093 smooth spline.

1094

1095

Figure 3: LOI profile for the Cors Fochno core.

1096

1097 Figure 4: Records of factors scores for the first four principal components.

1098 
Figure 5. Percentage microfossil diagram for selected taxa from Cors Fochno (a) trees,

1100 shrubs, spores, preservation and microscopic charcoal (b) herbs (c) non-pollen

1101 palynomorphs (NPPs).

1102

1103 Figure 6: Results from the inferred Changepoint analysis for the Cors Fochno pollen data.

1104 The weighted average model is shown as a solid red line, and the maximum likelihood

1105 model as a dashed black line. The gray filled area represents the statistical probability of a

1106 changepoint based on the posterior distribution for the model parameters (see Gallagher et

1107 al., 2011 for more details).

1108

1109 Figure 7: Detrended residual variance for $\mathrm{Pb}, \mathrm{Zn}$ and As.

1110

1111 Table 1: Radiocarbon dates from Cors Fochno (Borth Bog).

1112

1113 Table 2: Factor loadings from the PCA for the chemical elements from Cors Fochno.

1114

1115 Supplementary figure 1: PCA results of geochemical data (elemental composition).

1116 Percentage of explained variance (square of factor loadings) of the principal components

1117 extracted (diagonal lines - Cp1; pluses - Cp2; horizontal lines - Cp3; cross lines - Cp4).

1118

1119 Supplementary figure 2a: Profiles for $\mathrm{Si}, \mathrm{Al}, \mathrm{Ti}$ and $\mathrm{Rb}$ from the Cors Fochno core

1120

1121 Supplementary figure 2b: Profiles for $\mathrm{Pb}, \mathrm{Zn}$, As and Fe from the Cors Fochno core. 
1123 Supplementary figure 3. Percentage microfossil diagram for selected taxa from Cors Fochno

1124 (a) trees, shrubs, spores, preservation and microscopic charcoal (b) herbs (c) non-pollen

1125 palynomorphs (NPPs).

1126

1127 


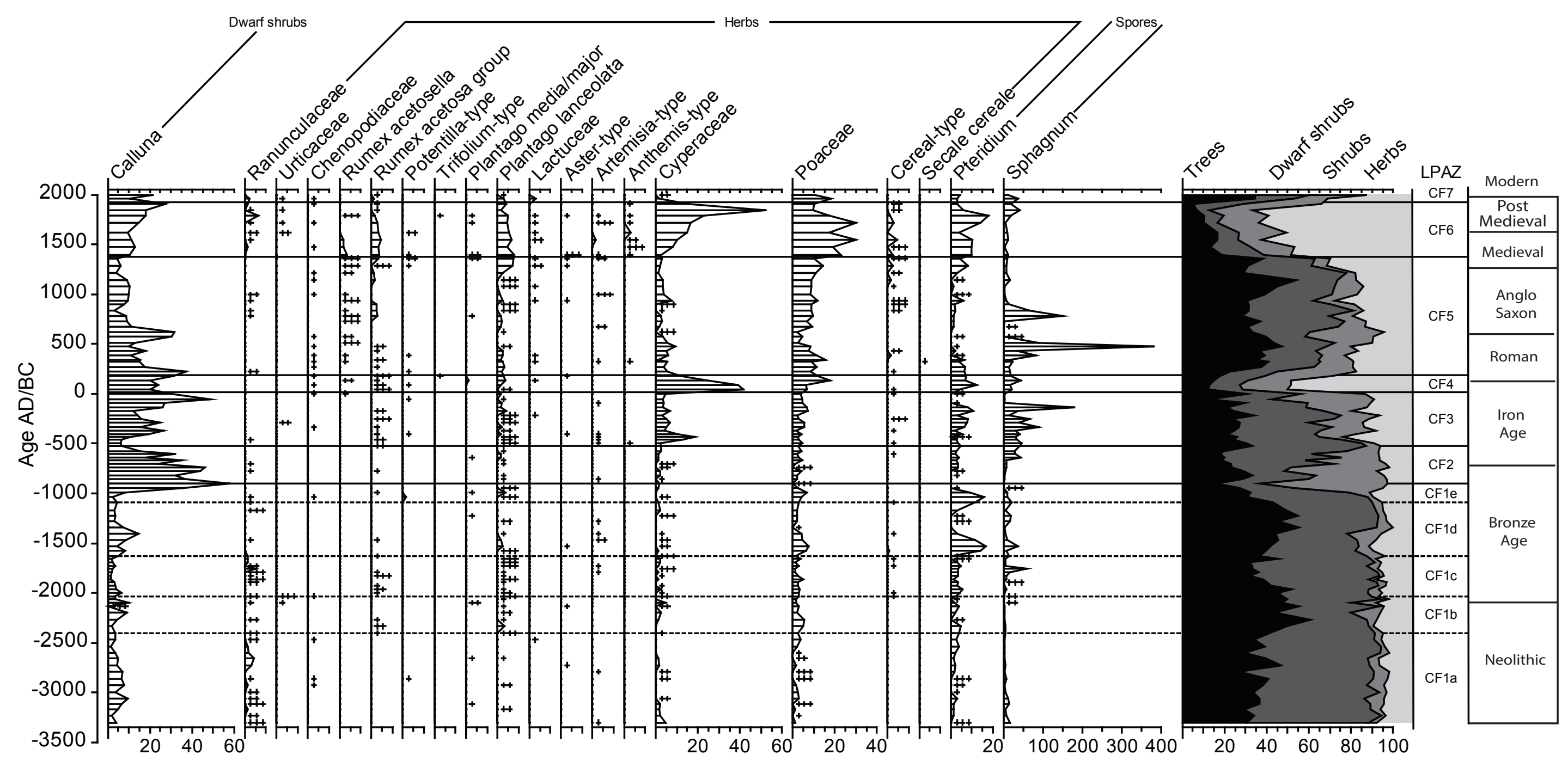




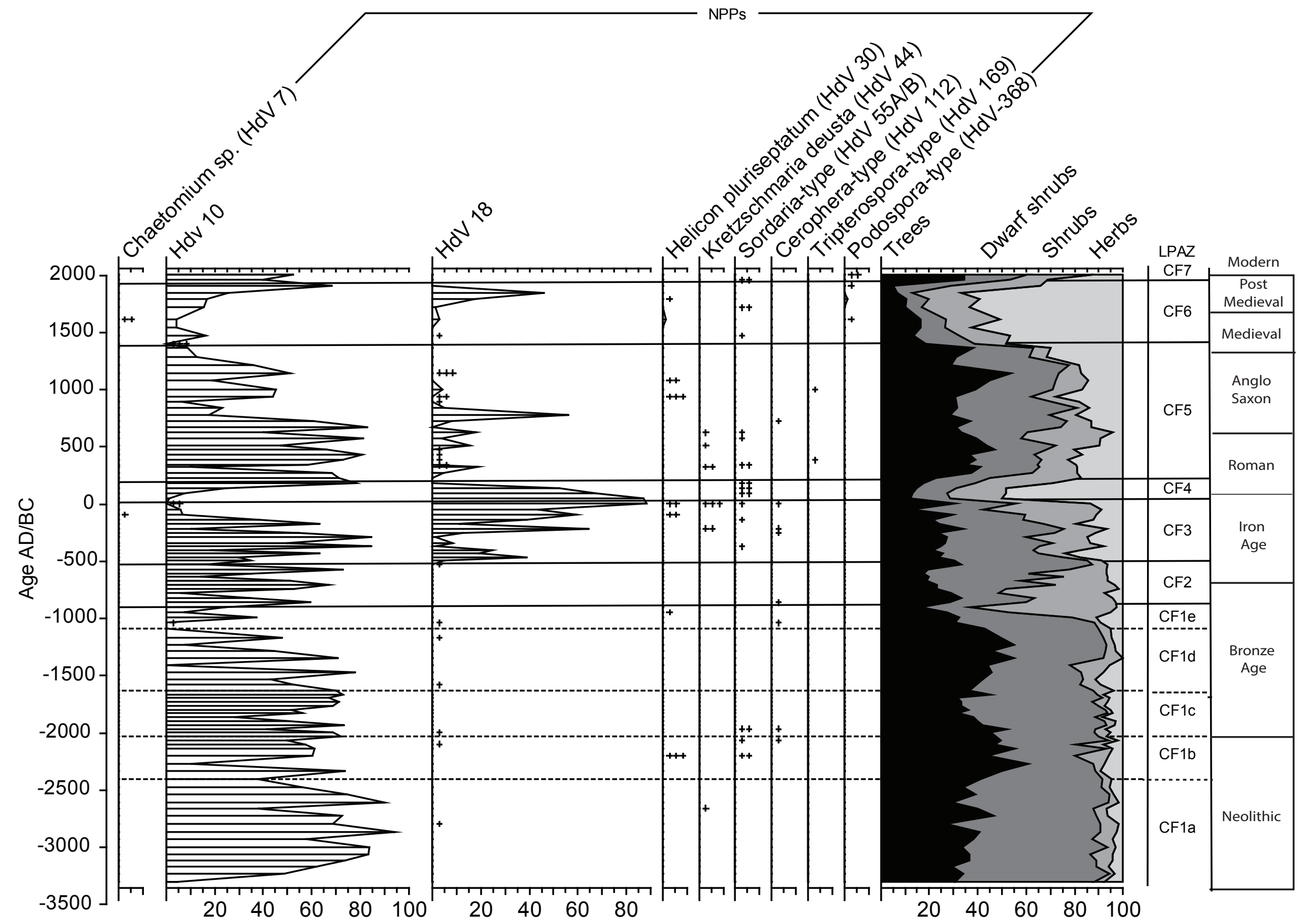




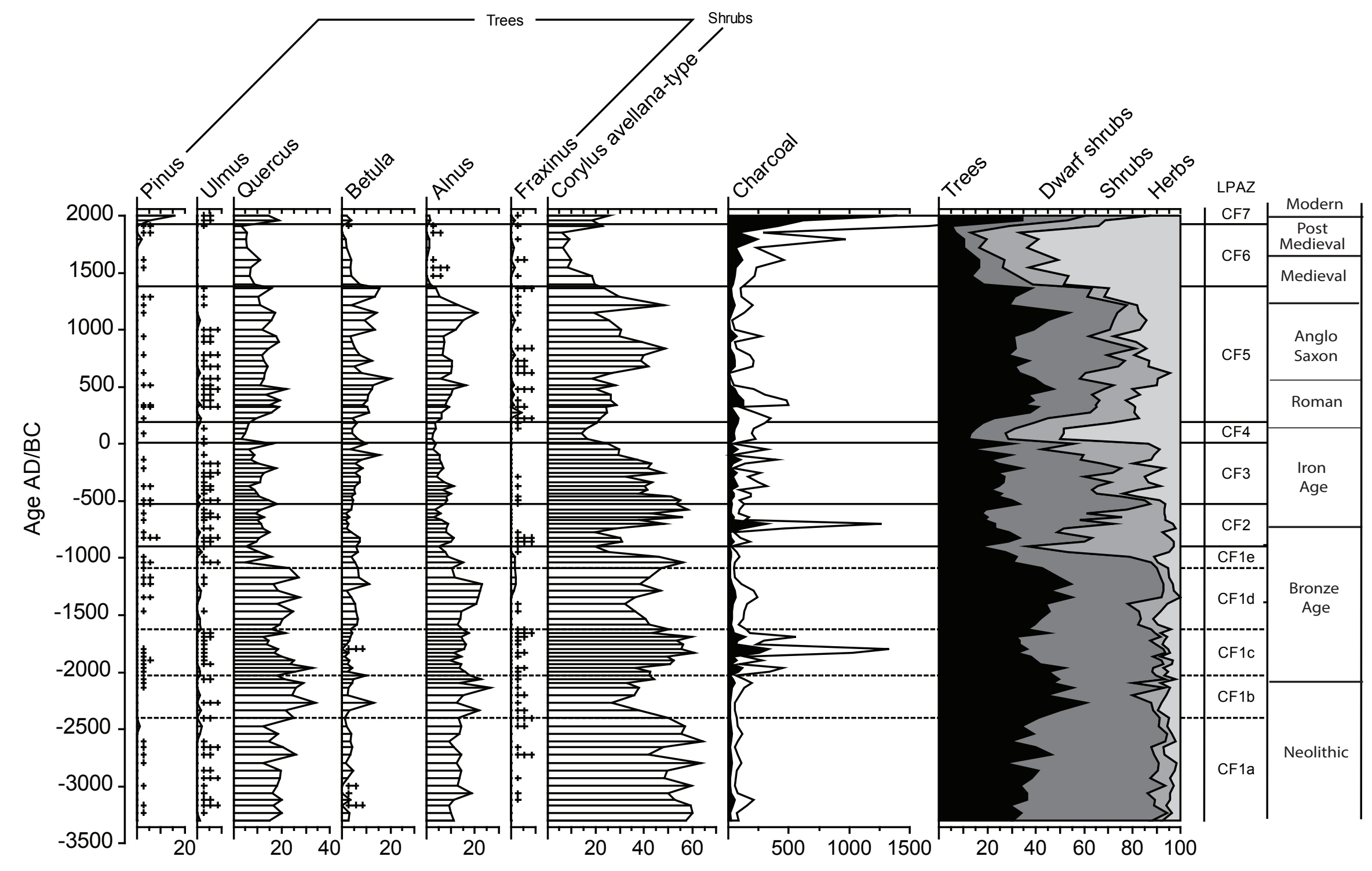




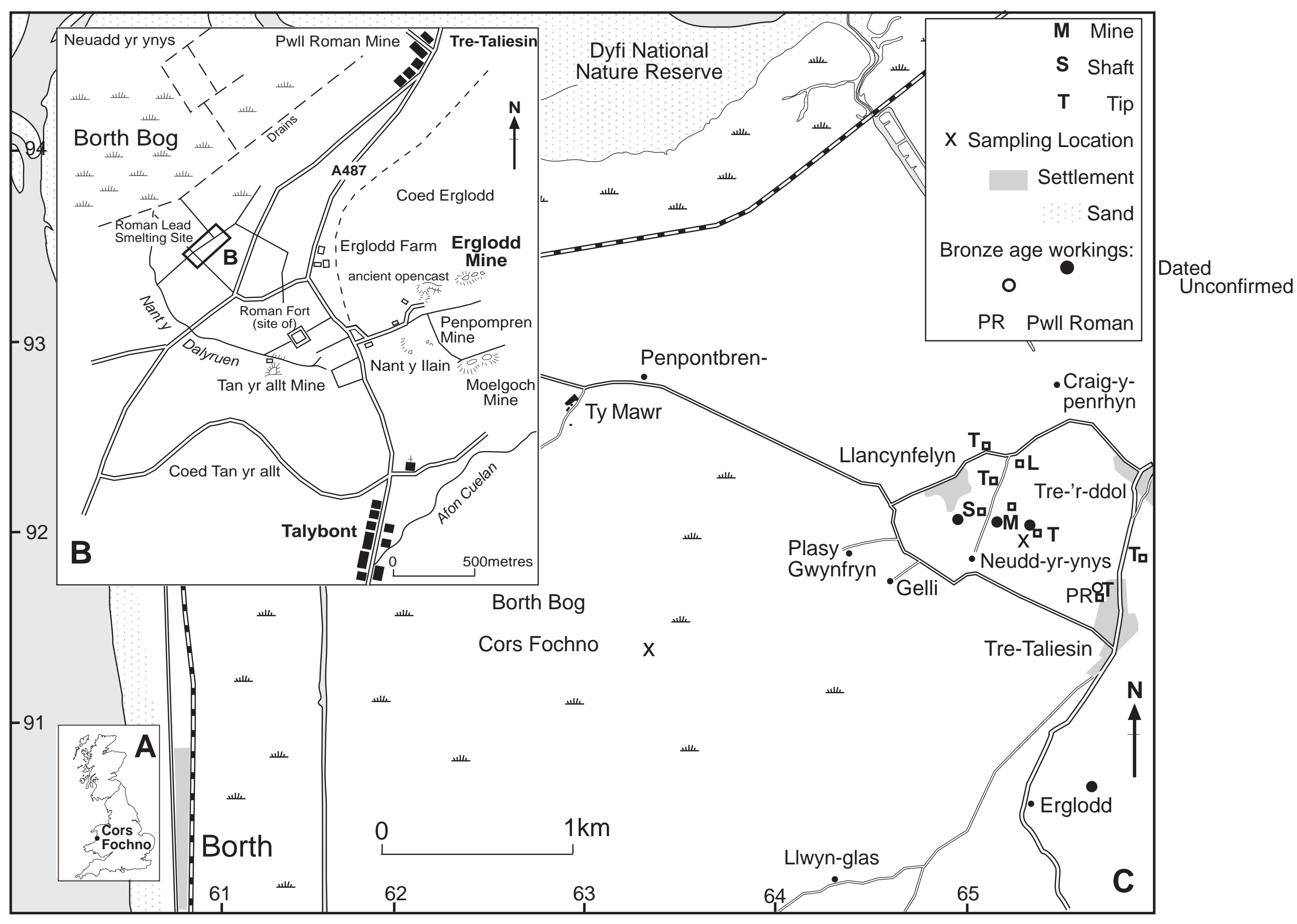




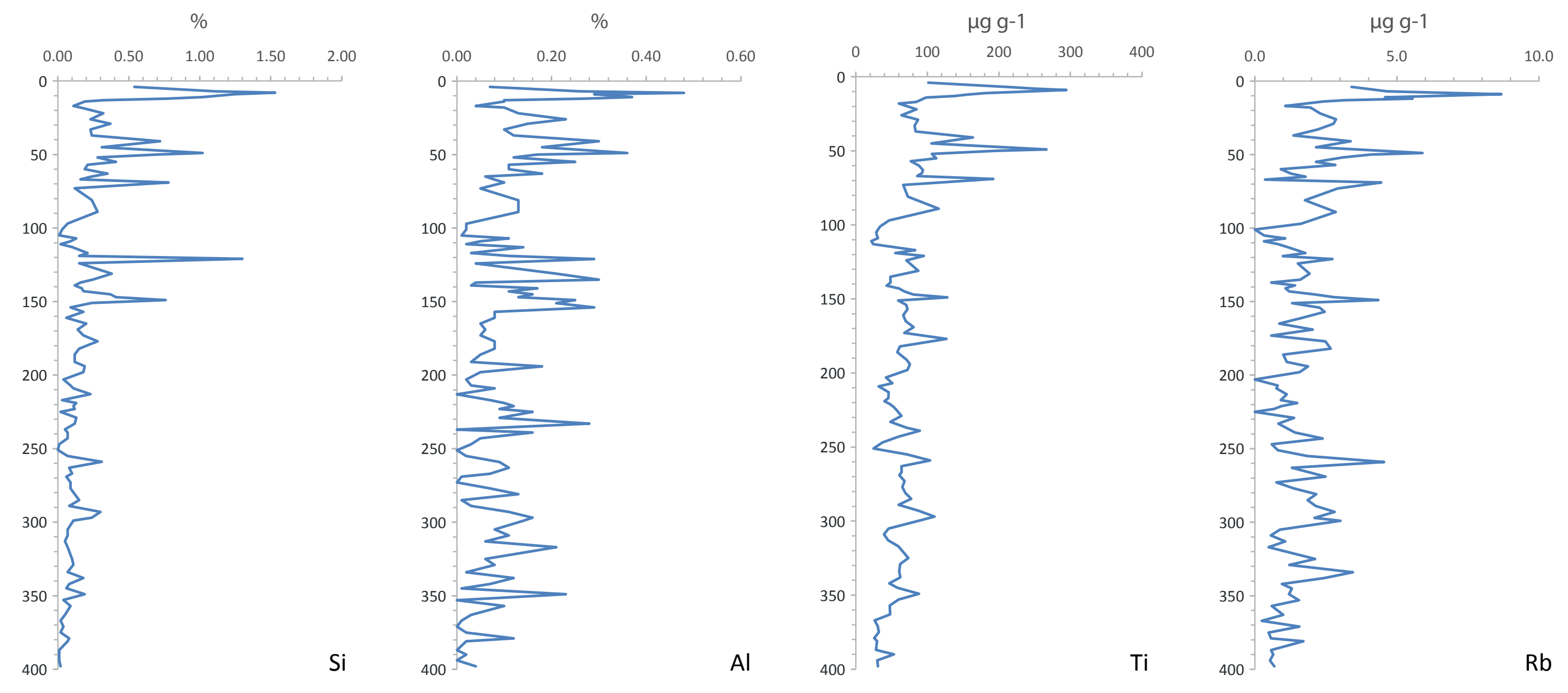



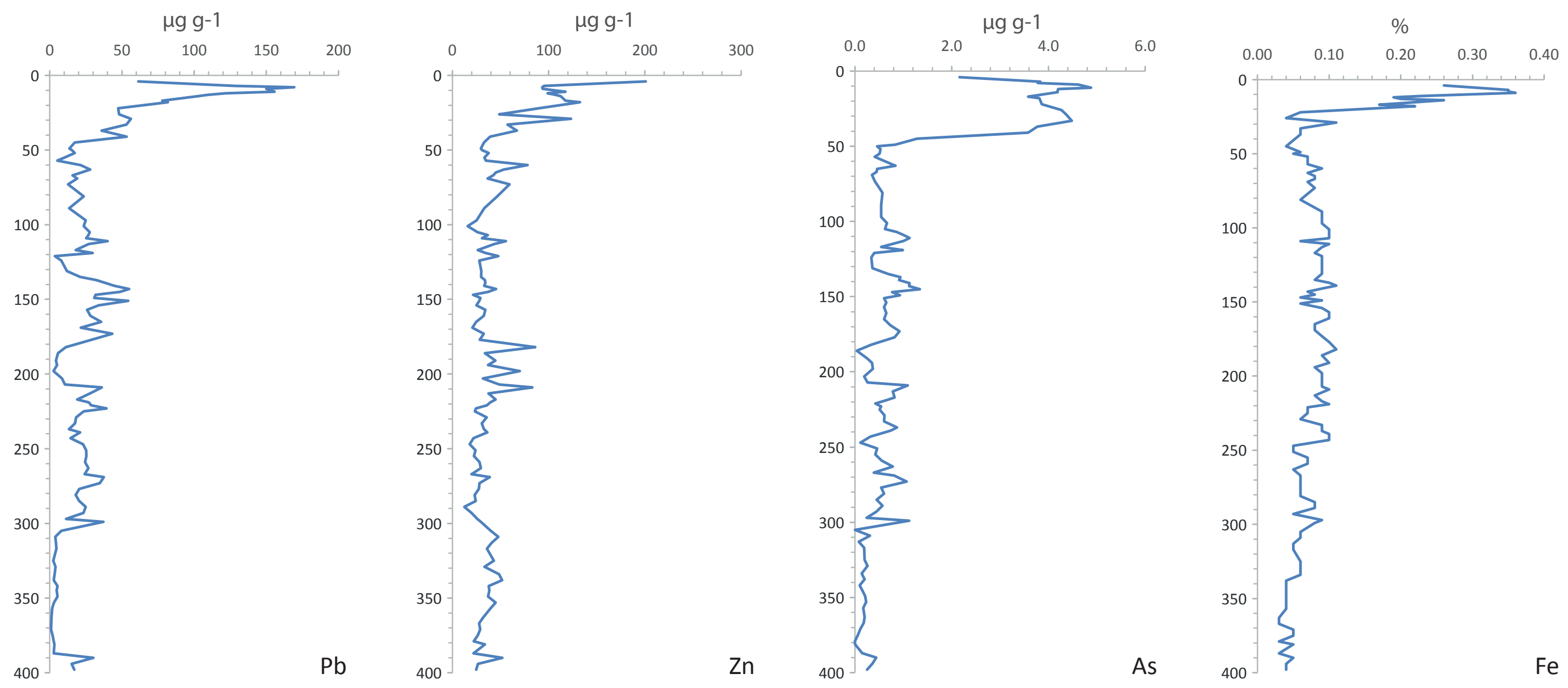


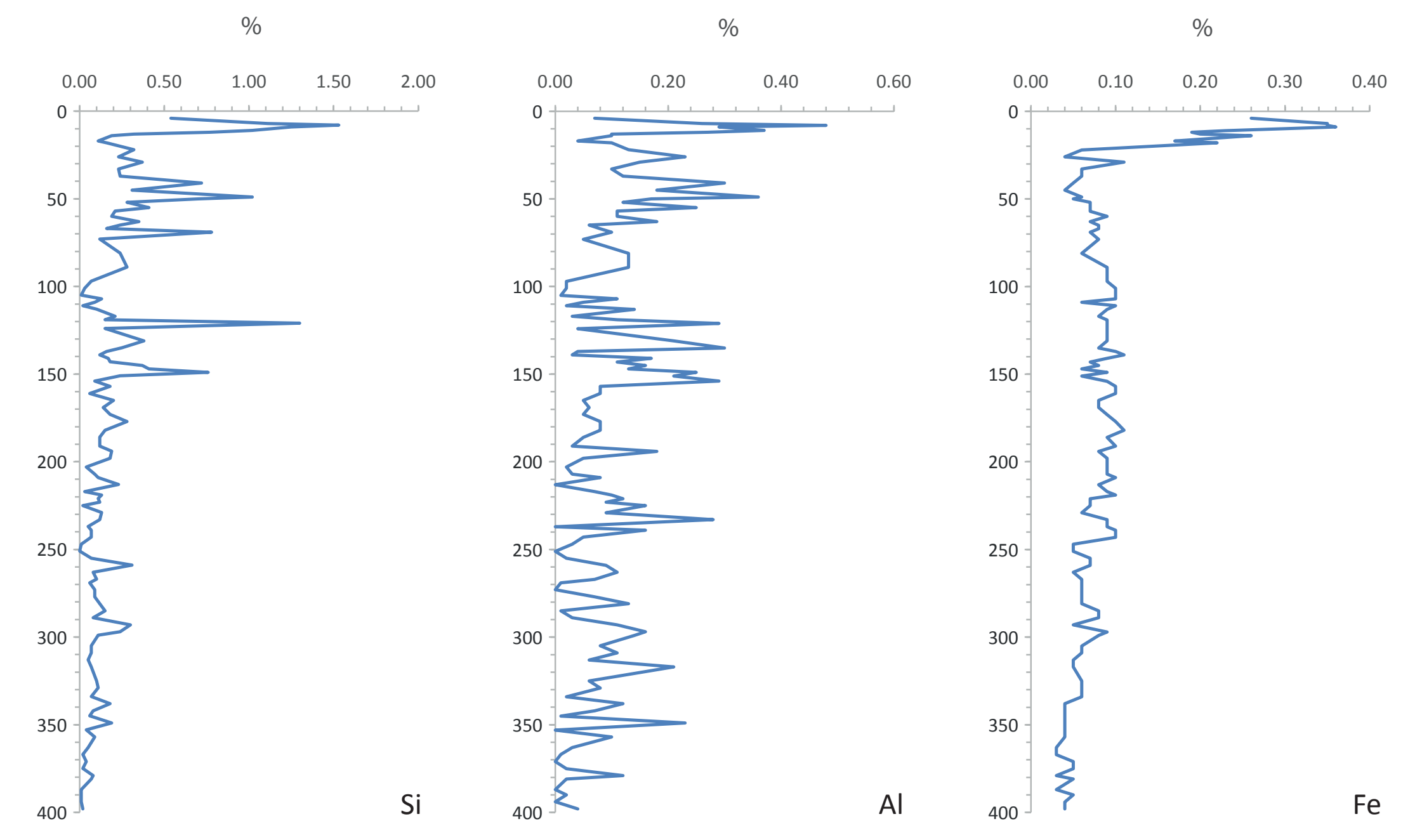




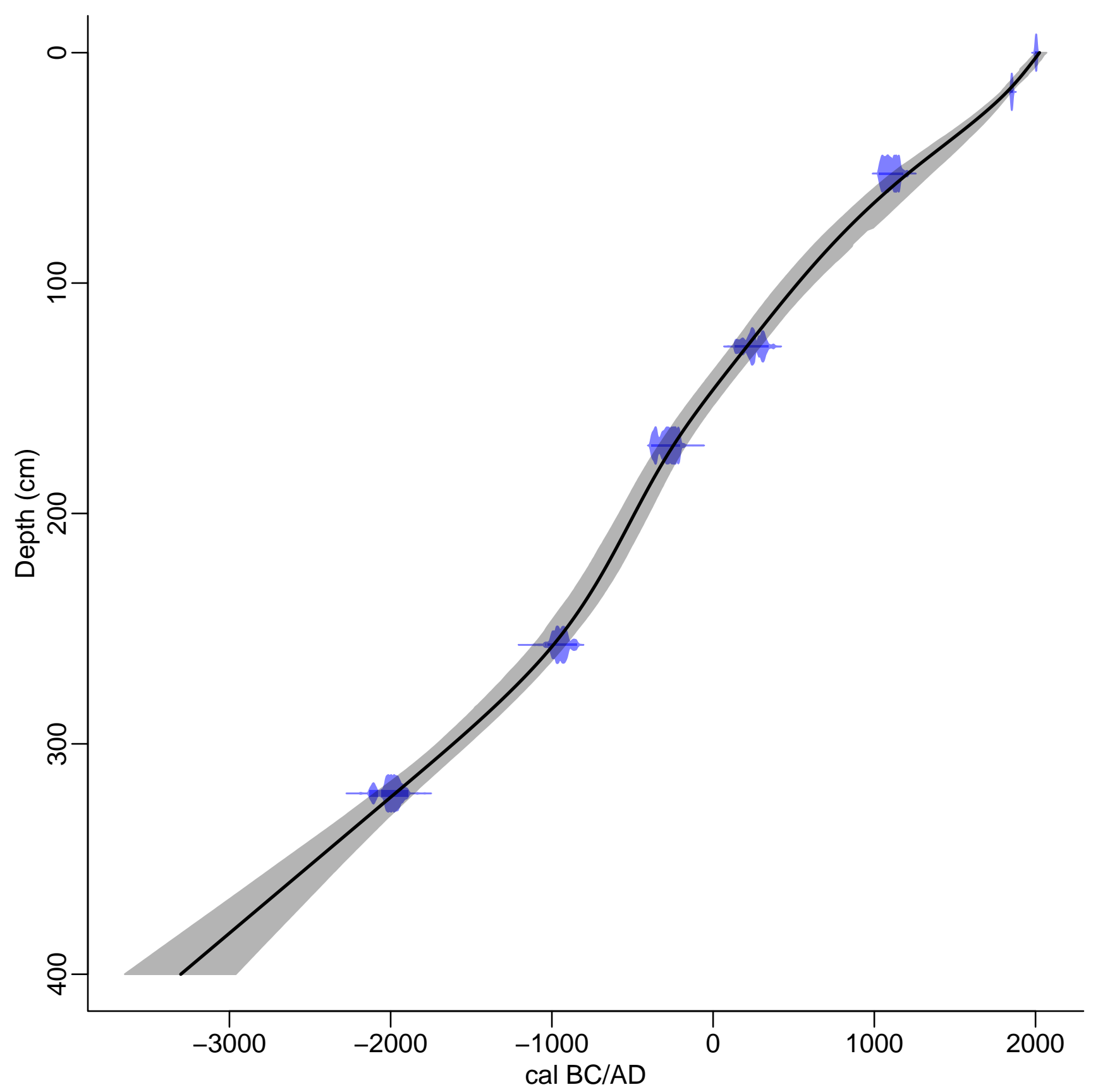




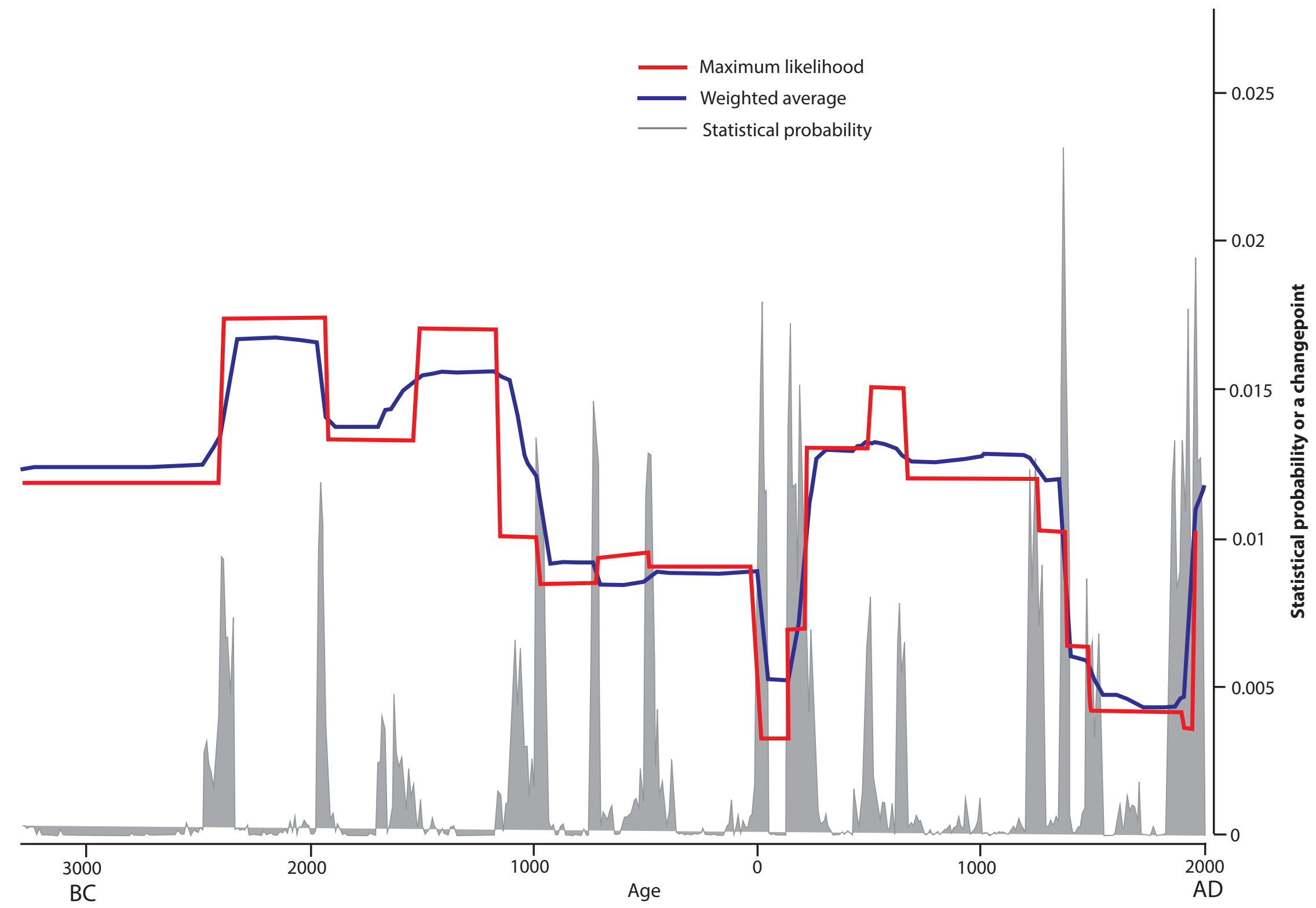




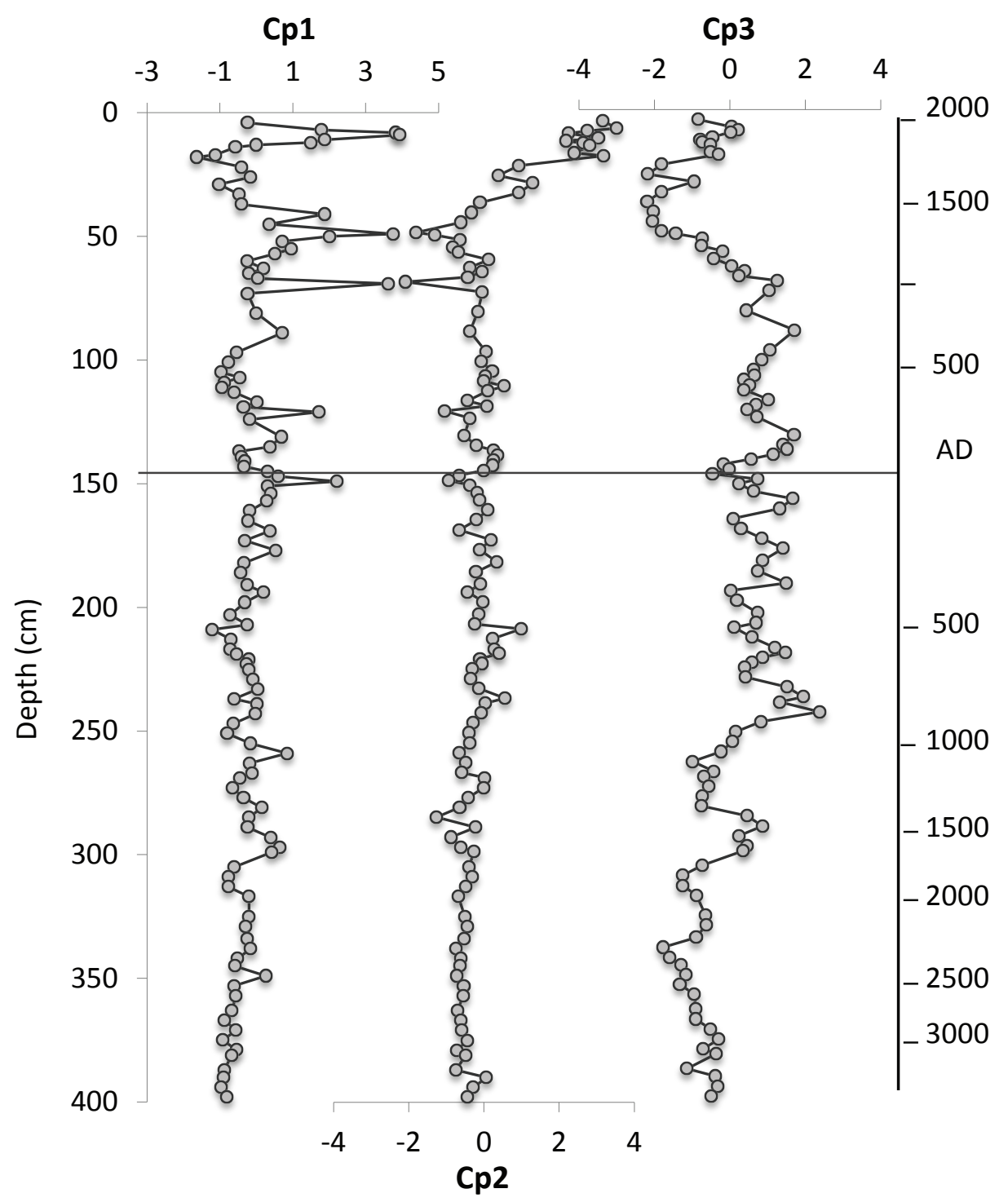

Factor Score 


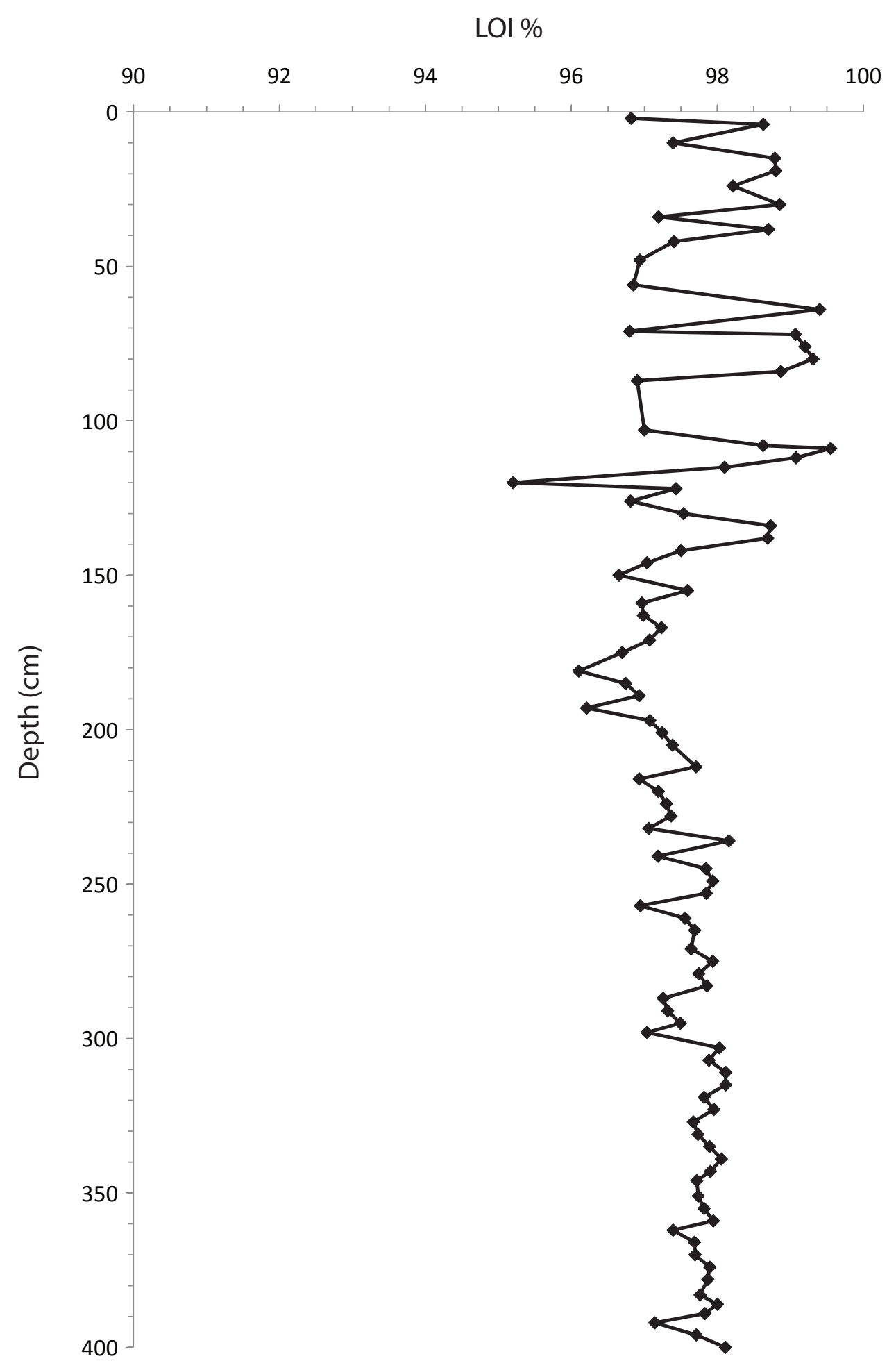


Table 1: Radiocarbon dates from Cors Fochno (Borth Bog).

Laboratory no. $\quad$ depth (cm) uncalibrated date calibrated age range (2 sigma)

$\begin{array}{llll}\text { Poz-25313 } & 52-53 & 925 \pm 30 & \text { cal AD 1026-1181 } \\ \text { Poz-17099 } & 128-129 & 1780 \pm 35 & \text { cal AD 134-338 } \\ \text { Poz-25314 } & 170-171 & 2225 \pm 35 & \text { cal BC 381-203 } \\ \text { Poz-25353 } & 257-257.5 & 2795 \pm 35 & \text { cal BC 1025-842 } \\ \text { Beta-180084 } & 320-323 & 3630 \pm 40 & \text { cal BC 2133-2081; 2060-1892 }\end{array}$




\begin{tabular}{|l|r|r|r|r|r|}
\hline \multicolumn{1}{|c|}{ Cp1 } & Cp2 & Cp3 & Cp4 \\
\hline $\mathrm{Ti}$ & $\mathbf{0 . 9 0}$ & 0.28 & -0.14 & 0.12 \\
\hline $\mathrm{Zr}$ & $\mathbf{0 . 8 8}$ & 0.06 & 0.01 & 0.20 \\
\hline $\mathrm{Ri}$ & $\mathbf{0 . 8 7}$ & 0.32 & -0.10 & 0.12 \\
\hline $\mathrm{Al}$ & $\mathbf{0 . 8 3}$ & 0.30 & -0.13 & 0.10 \\
\hline $\mathrm{Y}$ & $\mathbf{0 . 7 3}$ & 0.20 & -0.13 & -0.04 \\
\hline $\mathrm{K}$ & $\mathbf{0 . 7 2}$ & 0.60 & -0.13 & 0.09 \\
\hline $\mathrm{Fe}$ & $\mathbf{0 . 6 2}$ & 0.49 & -0.23 & 0.11 \\
\hline $\mathrm{Pb}$ & 0.40 & $\mathbf{0 . 8 5}$ & 0.17 & 0.06 \\
\hline $\mathrm{Zn}$ & 0.41 & $\mathbf{0 . 8 4}$ & -0.06 & -0.01 \\
\hline $\mathrm{As}$ & 0.07 & $\mathbf{0 . 8 2}$ & -0.24 & 0.20 \\
\hline $\mathrm{Cu}$ & 0.26 & $\mathbf{0 . 7 8}$ & -0.30 & 0.15 \\
\hline $\mathrm{Sr}$ & 0.42 & $\mathbf{0 . 7 7}$ & -0.11 & 0.19 \\
\hline $\mathrm{Ca}$ & -0.05 & -0.05 & 0.97 & -0.09 \\
\hline $\mathrm{Cr}$ & -0.33 & -0.28 & 0.87 & -0.15 \\
\hline $\mathrm{Ni}$ & 0.19 & 0.09 & -0.12 & 0.90 \\
\hline Eigv & 0.08 & 0.55 & -0.14 & $\mathbf{0 . 6 5}$ \\
\hline Var & 5.2 & 4.6 & 2.0 & 1.5 \\
\hline $\mathrm{aVar}$ & 32.4 & 28.7 & 12.8 & 9.1 \\
\hline
\end{tabular}

